\title{
Characterizing source fingerprints and ageing processes in laboratory-generated secondary organic aerosols using proton-nuclear magnetic resonance $\left({ }^{1} \mathrm{H}-\mathrm{NMR}\right)$ analysis and HPLC HULIS determination
}

\author{
Nicola Zanca ${ }^{1,5}$, Andrew T. Lambe ${ }^{2,3}$, Paola Massoli ${ }^{2}$, Marco Paglione ${ }^{1}$, David R. Croasdale ${ }^{3}$, Yatish Parmar ${ }^{3}$, \\ Emilio Tagliavini $^{4}$, Stefania Gilardoni ${ }^{1}$, and Stefano Decesari ${ }^{1}$ \\ ${ }^{1}$ Institute of Atmospheric Sciences and Climate (ISAC) of the National Research Council of Italy (CNR), \\ Bologna, 40129, Italy \\ ${ }^{2}$ Aerodyne Research Inc., Billerica, MA 01821, USA \\ ${ }^{3}$ Chemistry Department, Boston College, Chestnut Hill, MA 02467, USA \\ ${ }^{4}$ Department of Chemistry "Giacomo Ciamician", University of Bologna, Bologna, 40126, Italy \\ ${ }^{5}$ Proambiente S.c.r.1., Bologna, 40129, Italy
}

Correspondence to: Nicola Zanca (n.zanca@consorzioproambiente.it)

Received: 31 January 2017 - Discussion started: 13 February 2017

Revised: 4 July 2017 - Accepted: 24 July 2017 - Published: 6 September 2017

\begin{abstract}
The study of secondary organic aerosol (SOA) in laboratory settings has greatly increased our knowledge of the diverse chemical processes and environmental conditions responsible for the formation of particulate matter starting from biogenic and anthropogenic volatile compounds. However, characteristics of the different experimental setups and the way they impact the composition and the timescale of formation of SOA are still subject to debate. In this study, SOA samples were generated using a potential aerosol mass (PAM) oxidation flow reactor using $\alpha$-pinene, naphthalene and isoprene as precursors. The PAM reactor facilitated exploration of SOA composition over atmospherically relevant photochemical ageing timescales that are unattainable in environmental chambers. The SOA samples were analyzed using two state-of-the-art analytical techniques for SOA characterization - proton nuclear magnetic resonance ( ${ }^{1} \mathrm{H}-\mathrm{NMR}$ ) spectroscopy and HPLC determination of humiclike substances (HULIS). Results were compared with previous Aerodyne aerosol mass spectrometer (AMS) measurements. The combined ${ }^{1} \mathrm{H}-\mathrm{NMR}$, HPLC, and AMS datasets show that the composition of the studied SOA systems tend to converge to highly oxidized organic compounds upon prolonged $\mathrm{OH}$ exposures. Further, our ${ }^{1} \mathrm{H}-\mathrm{NMR}$ findings show that only $\alpha$-pinene SOA acquires spectroscopic features com-
\end{abstract}

parable to those of ambient OA when exposed to at least $1 \times 10^{12}$ molec $\mathrm{OH} \mathrm{cm}{ }^{-3} \times \mathrm{s} \mathrm{OH}$ exposure, or multiple days of equivalent atmospheric $\mathrm{OH}$ oxidation. Over multiple days of equivalent $\mathrm{OH}$ exposure, the formation of HULIS is observed in both $\alpha$-pinene SOA and in naphthalene SOA (maximum yields: 16 and $30 \%$, respectively, of total analyzed water-soluble organic carbon, WSOC), providing evidence of the formation of humic-like polycarboxylic acids in unseeded SOA.

\section{Introduction}

Organic aerosol (OA) constitutes a large proportion of ambient particulate matter, affecting the Earth's radiation balance, cloud formation and human health (Hallquist et al., 2009). Understanding and simulating the concentration and composition of OA particles is one of the major challenges of modern atmospheric chemistry. In the mid-2000s the discovery that oxidized organic compounds dominate in concentration compared to that of primary organic compounds outside urban areas (Zhang et al., 2007; Jimenez et al., 2009), together with the understanding that the ambient organic aerosol concentrations were systematically underpredicted 
by existing chemical transport models (Heald et al., 2005), led to a reevaluation of the treatment of secondary organic aerosol (SOA) formation processes in chemistry and climate models. Since the model-measurement gap is mostly overcome by subjecting the particles to "oxidative ageing", understanding the nature of ageing processes has become a primary objective of new generation SOA studies. Experimental findings showing the existence of highly oxidized SOA molecular tracers with a high oxygen-to-carbon $(\mathrm{O} / \mathrm{C})$ ratio (Szmigielski et al., 2007) and molecular structures that are chemically distinct from first- and second-generation oxidation products of the same precursors (Jenkin et al., 2000) have provided indirect confirmation of still unknown chemical processes forming highly oxidized, low-volatility compounds.

The first formulations of SOA ageing into models were based on the chemistry of saturated hydrocarbon oxidation by $\mathrm{OH}$, for which a step-by-step process with a slow, progressive increase in the oxidation state, along with a decrease in volatility, can be proposed (Robinson et al., 2007). The duration of such processes clearly exceeds the residence time of SOA in traditional environmental chamber experiments with equivalent atmospheric ageing times of less than 1 day. These limitations led to the emergence of oxidation flow reactors that are capable of higher integrated oxidant exposures, including the potential aerosol mass (PAM) oxidation flow reactor (Kang et al., 2007; Lambe et al., 2011) and related techniques (Hall IV et al., 2013; Keller and Burtscher, 2012; Slowik et al., 2012). Recent studies suggest that flowreactor-generated SOA particles have similar composition to SOA generated in chambers (Lambe et al., 2015; Bruns et al., 2015). Modeling work further suggests that flow reactors simulate tropospheric oxidation reactions with minimal experimental artifacts ( $\mathrm{Li}$ et al., 2015; Peng et al., 2015, 2016). Recent applications of oxidation flow reactors in field measurements showed that the maximum yields of SOA were attained at approximately 2-3 days of equivalent atmospheric $\mathrm{OH}$ oxidation; at higher photochemical age, SOA yields decrease substantially (Tkacik et al., 2014; Ortega et al., 2016; Palm et al., 2016). Such observations demonstrate the influence of fragmentation reactions in which oxidation leads to $\mathrm{C}-\mathrm{C}$ bond cleavage with the production of highly volatile products (Kroll et al., 2009; Chacon-Madrid and Donahue 2011; Lambe et al., 2012).

The idea of a slow, multi-generation SOA ageing was recently challenged by recent findings from reaction chamber experiments employing modern chemical ionization mass spectrometric methods. For example, it was found that oxidized gaseous compounds with $\mathrm{O} / \mathrm{C}>0.7$ form readily upon VOC oxidation (Ehn et al., 2012, 2014; Krechmer et al., 2015; Rissanen et al., 2014) and that even the chemical tracers of "aged" SOA can be in fact produced among second-generation oxidation products (Müller et al., 2012). The quantification of highly oxidized SOA compounds in reaction chambers is challenging because of significant va- por and particle wall losses (Matsunaga and Ziemann, 2010; Zhang et al., 2014; Krechmer et al., 2016; Ye et al., 2016), but these findings suggest that SOA ageing can be much faster than previously thought (Hodzic et al., 2016). As a result of the diverse implementations of SOA schemes in models, the quantification of SOA production and concentration in the atmosphere is still highly uncertain: a recent intercomparison between 20 state-of-the-art global models showed that the estimated SOA annual production rates differ by 1 order of magnitude (Tsigaridis et al., 2014). These results call for more experimental observations for constraining the existing SOA parameterizations.

The present study focuses on laboratory production of SOA from three different precursors using a PAM reactor. The novel feature of this work is our application of two offline analytical techniques that provide valuable insight in regards to SOA composition yet are rarely employed for SOA characterization. The first technique, ${ }^{1} \mathrm{H}-\mathrm{NMR}$ spectroscopy, is a universal technique in organic chemistry. It has been used to confirm the molecular structures of many SOA tracers (Finessi et al., 2014) or for following SOA reaction products in aqueous solution (Yu et al., 2011). The few examples of ${ }^{1} \mathrm{H}-$ NMR spectroscopy on SOA complex mixtures (Cavalli et al., 2006; Baltensperger et al., 2008; Bones et al., 2010; White et al., 2014) indicate that the technique can be very specific for distinguishing different biogenic and anthropogenic SOA systems. The present study is among the first applications of ${ }^{1} \mathrm{H}-\mathrm{NMR}$ spectroscopy to SOA samples produced from the $\mathrm{OH}$ oxidation of biogenic and anthropogenic SOA in the laboratory. The acquisition of ${ }^{1} \mathrm{H}-\mathrm{NMR}$ fingerprints for fresh and aged biogenic and anthropogenic SOA can also be useful for interpreting factor analysis results obtained on a timeline of ${ }^{1} \mathrm{H}-\mathrm{NMR}$ spectra of ambient aerosol extracts (e.g., Paglione et al., 2014a). The second technique is an HPLC setup for the determination of humic-like substances (HULIS). HULIS have been observed in ambient organic aerosol for nearly two decades (Havers et al., 1998; Limbeck et al., 2003), but their formation pathways aside from production in biomass burning plumes remain unclear (Graber and Rudich, 2006). It is well known that high-molecular-weight oxygenated organic compounds readily form by heterogeneous reactions (Limbeck et al., 2003) or by gas-to-particle conversion (Kalberer et al., 2006), but there is little evidence for their identification with HULIS in ambient aerosols (especially if we base the definition on the chromatographic behavior, as in Baduel et al., 2009).

Here we focus on SOA systems generated from three distinct precursors: isoprene, $\alpha$-pinene and naphthalene. Naphthalene is used as proxy for anthropogenic aromatic intermediate-volatility organic compounds (IVOCs). $\alpha$-Pinene is the most studied biogenic monoterpene due to its global importance as a biogenic SOA precursor (e.g., Pye et al., 2010), while isoprene is the most abundant biogenic VOC, accounting for $44 \%$ of global emissions (Guenter et al., 1995). The discovery of isoprene SOA is relatively recent 
(Claeys et al. 2004). In the presence of acidic wet aerosols, SOA originates from the heterogeneous uptake of isoprene epoxides ("IEPOX channel"; Lin et al., 2012). Since aerosol water and acidity are primarily determined by anthropogenic mineral acids, the formation of SOA from isoprene appears to be very much controlled by anthropogenic emissions. On the other hand, recent experiments conducted at very low nitrogen oxide (NO) concentrations, and in the absence of seed aerosols, have showed that SOA can still form from isoprene ("non-IEPOX" SOA; Krechmer et al., 2015). Such aerosols are more representative of the preindustrial world and their characterization is of paramount importance for understanding the climate radiative forcing of SOA at the global scale. Our results, obtained in the PAM reactors in the absence of $\mathrm{NO}_{x}$, are representative for non-IEPOX isoprene SOA.

\section{Experimental methods}

\subsection{PAM oxidation flow reactor}

The PAM oxidation flow reactor is a horizontal $13 \mathrm{~L}$ glass cylindrical chamber that is $46 \mathrm{~cm}$ long $\times 22 \mathrm{~cm}$ ID. Carrier gas flows of $8.5 \mathrm{~L} \mathrm{~min}^{-1} \mathrm{~N}_{2}$ and $0.5 \mathrm{~L} \mathrm{~min}^{-1} \mathrm{O}_{2}$ were used, with $8.5 \mathrm{~L} \mathrm{~min}^{-1}$ of flow pulled through the reactor and $0.5 \mathrm{~L} \mathrm{~min}^{-1}$ of excess flow removed prior to the reactor. Other experimental details are fully described in Lambe et al. (2011). In this study, the PAM reactor was connected to a scanning mobility particle sizer (SMPS), an Aerodyne time-of-flight aerosol mass spectrometer (AMS), and a filter holder equipped with $47 \mathrm{~mm}$ (prebaked) quartz-fiber filters. SOA concentrations calculated from SMPS and/or AMS measurements averaged over filter collection times provided an estimate of the organic matter loading on the filters.

During the first set of experiments involving $\alpha$-pinene and naphthalene as SOA precursors, by varying the concentrations of $\mathrm{OH}$ inside the PAM reactor, SOA with a different oxidation state could be obtained. For instance, the $\mathrm{OH}$ exposure varied from $2.0 \times 10^{11}$ molec cm $^{-3} \times \mathrm{s}$ to $2.1 \times 10^{12}$ molec $\mathrm{cm}^{-3} \times \mathrm{s}$ between the $\alpha$-pinene experiments and the resulting SOA oxidation degree - traced by the "f44" parameter (i.e., the fraction of the $m / z 44$ signal with respect to the total OA) - increased from 0.05 to 0.24. A total of five $\alpha$-pinene and five naphthalene SOA samples were obtained (collection time between 3 and $20 \mathrm{~h}$ ), with integrated $\mathrm{OH}$ exposures varying between $2 \times 10^{11}$ and $2 \times 10^{12}$ molec $\mathrm{cm}^{-3} \times \mathrm{s}$, corresponding to a photochemical age of 1.5 to 15 days assuming a $24 \mathrm{~h}$ average $\mathrm{OH}$ concentration of $1.5 \times 10^{6} \mathrm{molec} \mathrm{cm}^{-3}$ (Mao et al., 2009).

During the second set of experiments, isoprene SOA samples were generated in the reactor (Table 2). Due to the lower yields of SOA produced by isoprene oxidation, samples were collected at $\mathrm{OH}$ exposure of approximately $8 \times 10^{11}$ molec $\mathrm{cm}^{-3} \mathrm{~s}$ (corresponding to a photochemical age of 6 days) at which the maximum SOA yield is obtained
(Lambe et al., 2015). The collection time was varied between 2 and $18 \mathrm{~h}$.

To compare SOA formation processes occurring in oxidation flow reactors and in the atmosphere, two primary assumptions are required. First, we assume the kinetics of laboratory processes occurring at higher oxidant concentrations and shorter exposure times can be extrapolated to atmospheric processes occurring at lower oxidant concentrations and longer residence times. Second, we assume that the extent of nucleation or phase partitioning of SOA is not limited by the shorter residence time in flow reactors. The first assumption is supported by Renbaum and Smith (2011), Bahreini et al. (2012), and Lambe et al. (2015). The second assumption may introduce uncertainty depending on the particle surface area available to promote condensation and the mass accommodation coefficient of the oxidized vapors (Lambe et al., 2015; Shantanu et al., 2017).

\subsection{Extraction and offline sample characterization}

Each filter was extracted with $5 \mathrm{~mL}$ of deionized ultra-pure water (Milli-Q) in a mechanical shaker for $1 \mathrm{~h}$ and the water extract was filtered on PTFE membranes (pore size: $0.45 \mu \mathrm{m}$ ) in order to remove suspended particles. The water extracts were dried by rotary evaporator and were then re-dissolved in $2.15 \mathrm{~mL}$ of $\mathrm{D}_{2} \mathrm{O}: 0.65 \mathrm{~mL}$ for proton-nuclear magnetic resonance $\left({ }^{1} \mathrm{H}-\mathrm{NMR}\right)$ characterization (Decesari et al., 2000), and $1.5 \mathrm{~mL}$ for HPLC analysis and total organic carbon (TOC) analysis (Mancinelli et al., 2007). Tests of extraction using methanol instead of water were carried out on three isoprene SOA samples. The ${ }^{1} \mathrm{H}-\mathrm{NMR}$ spectra of methanol extracts were completely consistent with those obtained for the other three analyzed in deuterated water (Fig. S2 in the Supplement), indicating that there were no specific classes of water-insoluble compounds in the isoprene SOA under the conditions used in this study. The following discussion will focus on the water-soluble fraction for which spectroscopic and chromatographic data were obtained for all three SOA systems.

\section{$2.3 \quad{ }^{1}$ H-NMR spectroscopy}

The ${ }^{1} \mathrm{H}-\mathrm{NMR}$ spectra were acquired at $600 \mathrm{MHz}$ with a Varian 600 spectrometer in a $5 \mathrm{~mm}$ probe with $0.65 \mathrm{~mL}$ of each sample re-dissolved in $D_{2} \mathrm{O}$. Sodium 3-trimethylsilyl$\left(2,2,3,3-d_{4}\right)$ propionate (TSP- $\left.d_{4}\right)$ was used as the referred internal standard. A buffer of potassium deuterated formate/formic acid ( $\mathrm{pH} \sim 3.8$ ) was used in the second series of experiments (isoprene SOA) to stabilize the chemical shift of hydrogen atoms in acyl functional groups, while the extracts obtained during the first experiments ( $\alpha$-pinene and naphthalene) were analyzed unbuffered. ${ }^{1} \mathrm{H}-\mathrm{NMR}$ spectroscopy of low-concentration samples in protic solvents provides the speciation of hydrogen atoms bound to carbon atoms $(\mathrm{H}-\mathrm{C})$. On the basis of the range of frequency shifts (the chemi- 
Table 1. PAM experimental conditions for naphthalene and $\alpha$-pinene SOA ageing studies.

\begin{tabular}{|c|c|c|c|c|c|c|}
\hline Sample & $\begin{array}{l}\text { Oxidation } \\
\text { level }\end{array}$ & $\begin{array}{r}\text { PAM } \\
\text { lamp } \\
\text { voltage } \\
(\mathrm{V})\end{array}$ & $\begin{array}{r}\mathrm{OH} \text { exposure } \\
\left(\text { molec } \mathrm{cm}^{-3} \times \mathrm{s}\right)\end{array}$ & $\begin{array}{r}\text { Collection } \\
\text { Time (h) }\end{array}$ & $\begin{array}{r}\text { Average } \\
\text { AMS OM } \\
\text { concentration } \\
(\mathrm{RIE} \times \mathrm{CE}=1.4) \\
\left(\mu \mathrm{g} \mathrm{m}^{-3}\right)\end{array}$ & $\begin{array}{r}\text { OM on filter } \\
\text { based on AMS } \\
(\mathrm{RIE} \times \mathrm{CE}=1.4) \\
(\mu \mathrm{g})\end{array}$ \\
\hline \multicolumn{7}{|c|}{$\alpha$-Pinene } \\
\hline Pin\#1 & $\begin{array}{l}\text { High } \\
(\mathrm{f} 44=0.24)\end{array}$ & 110 & $2.10 \times 10^{12}$ & 18.5 & 46.1 & 384 \\
\hline Pin\#2 & $\begin{array}{l}\text { Med. } \\
(\mathrm{f} 44=0.11)\end{array}$ & 75 & $1.10 \times 10^{12}$ & 3.2 & 151.6 & 221 \\
\hline Pin\#3 & $\begin{array}{l}\text { Med. } \\
(\mathrm{f} 44=0.11)\end{array}$ & 75 & $1.10 \times 10^{12}$ & 20.2 & 14.1 & 129 \\
\hline Pin\#5 & $\begin{array}{l}\text { Low } \\
(\mathrm{f} 44=0.05)\end{array}$ & 30 & $2.00 \times 10^{11}$ & 20.5 & 7.5 & 69 \\
\hline Pin\#6 & $\begin{array}{l}\text { Low } \\
(\mathrm{f} 44=0.05)\end{array}$ & 30 & $2.00 \times 10^{11}$ & 7.1 & 50.3 & 161 \\
\hline \multicolumn{7}{|c|}{ Naphthalene } \\
\hline Nap\#1 & $\begin{array}{l}\text { High } \\
\mathrm{f} 44=0.30)\end{array}$ & 110 & $2.10 \times 10^{12}$ & 19.7 & 31.3 & 277 \\
\hline Nap\#2 & $\begin{array}{l}\text { Med. } \\
(\mathrm{f} 44=0.19)\end{array}$ & 75 & $1.10 \times 10^{12}$ & 7 & 55.3 & 174 \\
\hline Nap\#3 & $\begin{array}{l}\text { Low } \\
(\mathrm{f} 44=0.084)\end{array}$ & 30 & $2.00 \times 10^{11}$ & 6.6 & 16.9 & 50 \\
\hline Nap\#4 & $\begin{array}{l}\text { Med } \\
(\mathrm{f} 44=0.20)\end{array}$ & 75 & $1.10 \times 10^{12}$ & 6.6 & 42.9 & 127 \\
\hline Nap\#5 & $\begin{array}{l}\text { Low } \\
(\mathrm{f} 44=0.074)\end{array}$ & 30 & $2.00 \times 10^{11}$ & 15.8 & 34.7 & 246 \\
\hline \multicolumn{7}{|l|}{ Blanks } \\
\hline Blk\#1 & & 110 & $2.10 \times 10^{12}$ & 6.1 & 0 & 0 \\
\hline Blk\#2 & & 110 & $2.10 \times 10^{12}$ & 23.2 & 0 & 0 \\
\hline Blk\#3 & & 110 & $2.10 \times 10^{12}$ & 6.1 & 0 & 0 \\
\hline
\end{tabular}

cal shift, in ppm) in which the ${ }^{1} \mathrm{H}-\mathrm{NMR}$ resonances occur, they can be attributed to different $\mathrm{H}$-C-containing functional groups (Paglione et al., 2014a).

\subsection{HPLC-UV-TOC method}

HULIS were determined using the ion exchange chromatographic method described by Mancinelli et al. (2007). A HPLC system (Agilent model 1100) with gradient elution was used. The subsequent elution of chemical compounds bearing zero, one, two or more than two ionized groups per molecule (mainly carboxylate ions at $\mathrm{pH} 7$ ) is monitored by a UV detector at $260 \mathrm{~nm}$. Downstream of the detector, a fraction collector is programmed to sample separately "neutral compounds" (NCs), "monocarboxylic acids" (MAs), "dicarboxylic acids" (DAs), and "polycarboxylic acids" (PAs) or HULIS. The amount of WSOC recovered in each fraction is determined offline by TOC analysis using an Analytik-Jena multi-analyzer N/C (model 2100). The HPLC column and chromatographic conditions used in this study were the same as in Mancinelli et al. (2007). Further information on the nature of the chemical classes separated by the HPLC method based on elution tests of standard compounds, including discussion of possible misclassification, is reported by Decesari et al. (2005).

\section{Results}

\section{$3.1{ }^{1}$ H-NMR results}

\subsection{1 ${ }^{1} \mathrm{H}$-NMR fingerprints of fresh and aged $\alpha$-pinene SOA}

Figure 1 shows the ${ }^{1} \mathrm{H}-\mathrm{NMR}$ spectra of $\alpha$-pinene SOA with increasing photochemical age. The first spectrum corresponding to a "low" SOA oxidation level is similar 
Table 2. PAM experimental conditions for isoprene SOA ageing studies.

\begin{tabular}{|c|c|c|c|c|c|c|}
\hline Sample & $\begin{array}{l}\text { Oxidation } \\
\text { level }\end{array}$ & $\begin{array}{r}\text { PAM } \\
\text { lamp } \\
\text { voltage } \\
(\mathrm{V})\end{array}$ & $\begin{array}{r}\text { OH exposure } \\
\left(\text { molec } \mathrm{cm}^{-3} \times \mathrm{s}\right)\end{array}$ & $\begin{array}{r}\text { Collection } \\
\text { Time (h) }\end{array}$ & $\begin{array}{r}\text { Average } \\
\text { AMS OM } \\
\text { concentration } \\
(\mathrm{RIE} \times \mathrm{CE}=1.4) \\
\left(\mu \mathrm{g} \mathrm{m}^{-3}\right)\end{array}$ & $\begin{array}{r}\text { OM on filter } \\
\text { based on AMS } \\
(\mathrm{RIE} \times \mathrm{CE}=1.4) \\
(\mu \mathrm{g})\end{array}$ \\
\hline \multicolumn{7}{|l|}{ Isoprene } \\
\hline Iso\#1 & $\begin{array}{l}\text { Med } \\
(\mathrm{f} 44=0.046)\end{array}$ & 60 & $7.8 \times 10^{11}$ & 3.7 & 409 & 651 \\
\hline Iso\#2 & $\begin{array}{l}\text { Med } \\
\text { (f44 = N.A.) }\end{array}$ & 60 & $7.8 \times 10^{11}$ & 2.8 & 575 & 700 \\
\hline Iso\#3 & $\begin{array}{l}\text { Med } \\
(\mathrm{f} 44=0.039)\end{array}$ & 60 & $7.8 \times 10^{11}$ & 2.2 & 678 & 656 \\
\hline Iso\#4 & $\begin{array}{l}\text { Med } \\
(\mathrm{f} 44=0.037)\end{array}$ & 60 & $7.8 \times 10^{11}$ & 2.9 & 551 & 684 \\
\hline Iso\#5 & $\begin{array}{l}\text { Med } \\
(\mathrm{f} 44=0.040)\end{array}$ & 60 & $7.8 \times 10^{11}$ & 16.1 & 685 & 4959 \\
\hline Iso\#6 & $\begin{array}{l}\text { Med } \\
(\mathrm{f} 44=0.066)\end{array}$ & 60 & $7.8 \times 10^{11}$ & 3.9 & 767 & 1280 \\
\hline Iso\#7 & $\begin{array}{l}\text { Med } \\
(\mathrm{f} 44=0.059)\end{array}$ & 60 & $7.8 \times 10^{11}$ & 3.8 & 593 & 986 \\
\hline \multicolumn{7}{|l|}{ Blanks } \\
\hline Blk\#1 & & 60 & $7.8 \times 10^{11}$ & 15.9 & 0 & 0 \\
\hline Blk\#2 & & 60 & $7.8 \times 10^{11}$ & 3.1 & 0 & 0 \\
\hline Blk\#3 & & 60 & $7.8 \times 10^{11}$ & 16.3 & 0 & 0 \\
\hline
\end{tabular}

to reported ${ }^{1} \mathrm{H}-\mathrm{NMR}$ spectra of environmental chambergenerated $\alpha$-pinene ozonolysis (Cavalli et al., 2006). However, the ${ }^{1} \mathrm{H}-\mathrm{NMR}$ fingerprint of $\alpha$-pinene SOA evolves rapidly with further oxidation steps. A clear, progressive disappearance of first-generation oxidation products (pinic and pinonic acid) with an increasing $\mathrm{O} / \mathrm{C}$ ratio can be observed. In the ${ }^{1} \mathrm{H}-\mathrm{NMR}$ spectra corresponding to a "medium" SOA oxidation level, the resonance at $0.83 \mathrm{ppm}$ of chemical shift, arising from one of the two gem-methyls of pinonic acid, accounts for only $0.3 \%$ of the total integral of the spectrum, while it represented $2-3 \%$ in the fresh SOA samples. This indicates that $\alpha$-pinene SOA composition evolves rapidly towards more highly oxidized molecular structures, with little resemblance to first-generation oxidation products. At "medium" and "high" oxidation levels, the unsubstituted alkyl groups of the SOA mixture give rise to a broad Gaussian band between 1.1 and $1.8 \mathrm{ppm}$ of chemical shift with a maximum at $1.4-1.5 \mathrm{ppm}$. The middle point position showing a slight deshielding with respect to a purely alkylic chain ( $\sim 1.3 \mathrm{ppm}$ for fatty acids) indicates the presence of electronegative groups (such as oxygen atoms) in beta or gamma position with respect to these alkyl groups. The band between 1.9 and $3 \mathrm{ppm}$, attributable to $\mathrm{C}-\mathrm{H}$ groups of acyl groups $(\mathrm{HC}-\mathrm{C}=\mathrm{O})$, also shows a transition towards structures containing more deshielded $\mathrm{H}$ atoms. In all cases, the most conspicuous band in this spectral region is found at 2.2-2.3 ppm of chemical shift, which corresponds to acetyl and acyl groups of aliphatic compounds with a low $\mathrm{O} / \mathrm{C}$ ratio, like pinonic acid $\left(R-\mathrm{CH}_{2}-\mathrm{C}=\mathrm{O}\right.$ and $\mathrm{CH}_{3}-(\mathrm{C}=\mathrm{O})-R$, where $R$ is mainly a $\mathrm{C}_{x} \mathrm{H}_{2 x+1}$ radical). Such a band persists in all SOA samples, but an additional band between 2.5 and $2.9 \mathrm{ppm}$ is observed in the two samples with the highest $\mathrm{O} / \mathrm{C}$ ratio, indicating that the aliphatic groups become more and more substituted by electronegative groups: the keto and carboxylic groups become spaced by no more than two methylene (or methyns) groups $(x(\mathrm{C}=\mathrm{O})-\mathrm{CH}-\mathrm{CH}-$ $(\mathrm{C}=\mathrm{O}) X$, where $X$ is a generic substituent). Finally, the ${ }^{1} \mathrm{H}-$ NMR resonances in the third important aliphatic region of alkoxy groups (CH-O), between 3.3 and $4.2 \mathrm{ppm}$ of chemical shift, are always relatively small, with peak intensity at intermediate photochemical age. SOA species that contribute to ${ }^{1} \mathrm{H}-\mathrm{NMR}$ resonance in this region may be correlated with semivolatile, highly functionalized species that contribute to maximum SOA yields observed at intermediate $\mathrm{OH}$ exposures (Lambe et al., 2015).

Overall, the ${ }^{1} \mathrm{H}$-NMR fingerprint of $\alpha$-pinene SOA is highly dependent on photochemical age, with a sharp change already at medium ageing. The most oxidized samples show spectral features that have lost any clear similarity with those 


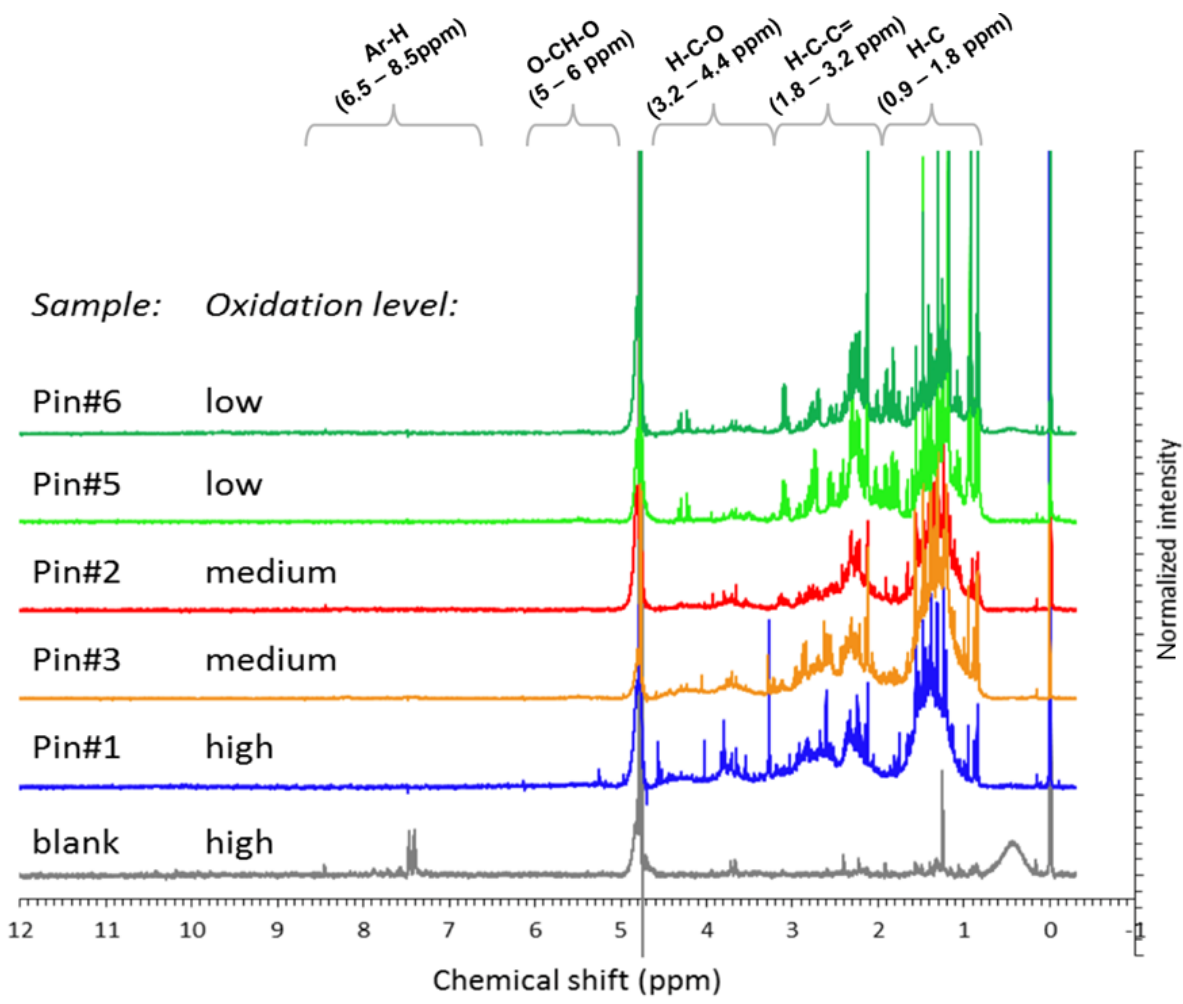

Figure 1. ${ }^{1} \mathrm{H}$-NMR spectra of $\alpha$-pinene SOA as a function of increasing photochemical age in the potential aerosol mass (PAM) oxidation flow reactor. The sharp singlet at 0 ppm represents the internal standard (TSP- $d_{4}$ ), while the broad peak at 4.8 ppm is the - partly instrumentally suppressed - hydrogen deuterium oxygen (HDO) peak. The sharp singlets between 0.9 and 2.2 ppm in the fresh SOA samples (Pin\#5 and Pin\#6) are genuine bands of the samples and were identified as methyl groups of pinic and pinonic acid.

of SOA sampled in reaction chambers experiments without ageing (Cavalli et al., 2006).

\subsection{2 ${ }^{1} \mathrm{H}$-NMR fingerprints of fresh and aged naphthalene SOA}

The ${ }^{1} \mathrm{H}-\mathrm{NMR}$ spectra of naphthalene SOA samples with an increasing $\mathrm{O} / \mathrm{C}$ ratio are presented in Fig. 2. The extract of the least-oxidized sample (on the top) shows broad resonances between 0 and $3 \mathrm{ppm}$ probably due to the effect of colloidal hydrophobic material in solution. Despite such an artifact, all spectra of fresh and moderately aged SOA show clear signals from aromatic structures (region at chemical shift from 6.5 to $8.5 \mathrm{ppm}$ ) and alkenes (approximately between 5 and $7 \mathrm{ppm}$ ). The ${ }^{1} \mathrm{H}-\mathrm{NMR}$ spectra of naphthalene SOA are very different than ${ }^{1} \mathrm{H}$-NMR spectra of SOA produced from the $\mathrm{OH}$ oxidation of one-ring aromatic VOCs (Baltensperger et al., 2008), which have mostly aliphatic groups originating from ring opening reactions. Our data are in agreement with molecular speciation studies (Lee and Lane 2009), indicating that naphthalene is oxidized to form one- or two-ring aromatic compounds such as naphthol, as well as substituted benzoquinones, cinnamic acid, and phthalic acid (Chhabra et al., 2015). The chemical shift range of the main aromatic band, between 7.4 and $8.1 \mathrm{ppm}$, indicates that aromatic rings are substituted prevalently by electron-withdrawing groups, such as carbonyl and carboxyls. At moderate ageing states, a small band at 6.9-7.1 ppm indicates the formation of phenolic structures. The ${ }^{1} \mathrm{H}$-NMR spectra of fresh naphthalene SOA show several singlets in the aromatic region, indicating a diversity of individual compounds occurring in relatively high concentrations, while moderately aged SOA show mainly the two singlets of phthalic acid. All spectra contain signals at lower chemical shifts with respect to the aromatics, mainly between 3.5 and $6.0 \mathrm{ppm}$ (with the interference of the partly suppressed peak of water in the middle): several functional groups can give rise to these bands, including alkoxyls, peroxides, esters, hemiacetals and acetals, and vinyls.

The spectrum of the most aged sample (NAPTH 1), which is also the one with the lowest SOA concentration, shows an interference from $\alpha$-pinene SOA in the aliphatic region. This feature is likely due to experimental setting contamination from a previous $\alpha$-pinene SOA experiment. Despite the low naphthalene SOA concentration, a broad aromatic band between 6.5 and $8.5 \mathrm{ppm}$ and the same signals found between 3.5 and $6.0 \mathrm{ppm}$ seen in the samples with a medium $\mathrm{O} / \mathrm{C}$ ratio are still visible in this most aged naphthalene SOA spectrum. However, the band from oxygenated functional groups between 3 and $4.5 \mathrm{ppm}$ becomes relatively more intense with 


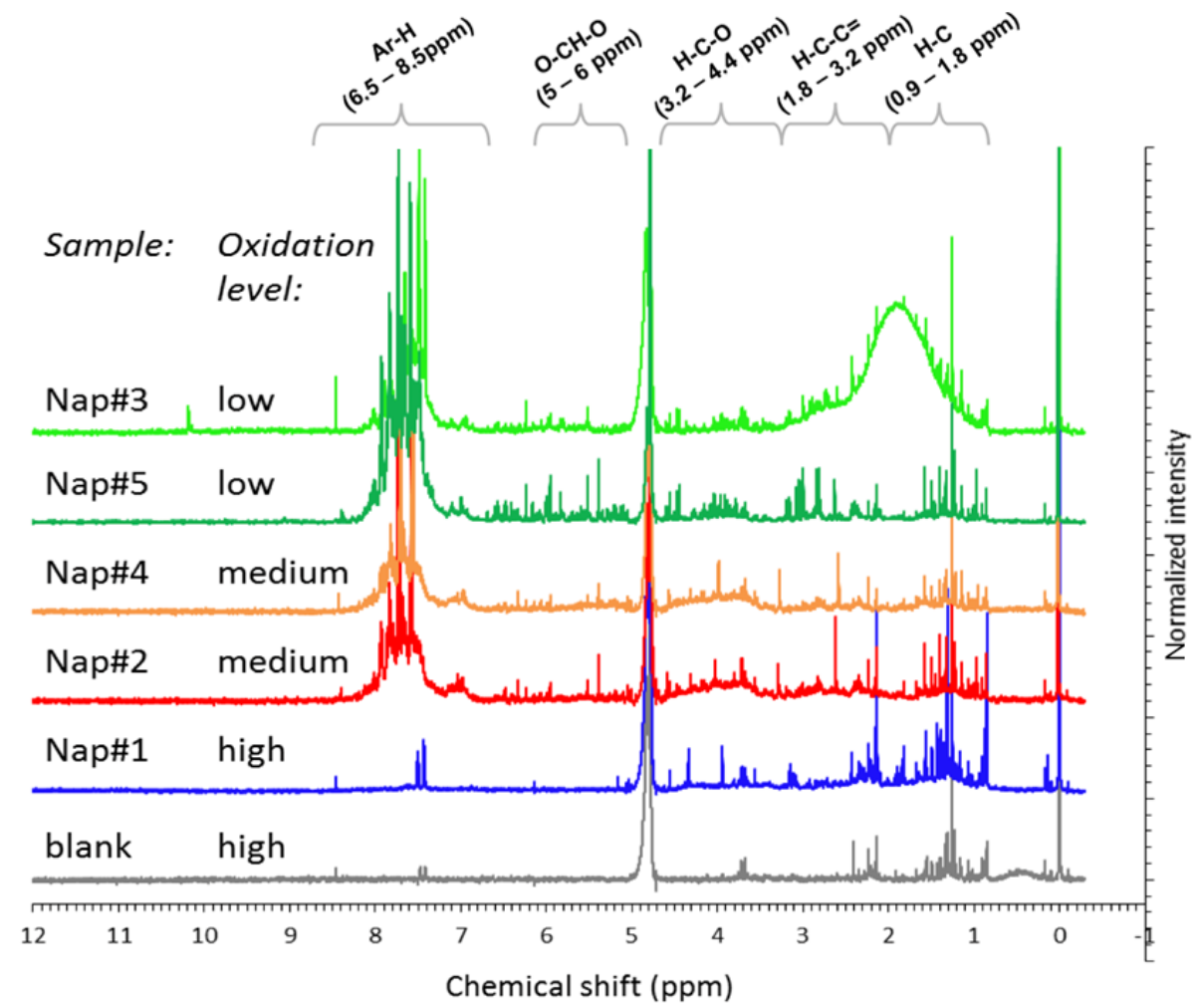

Figure 2. ${ }^{1} \mathrm{H}-\mathrm{NMR}$ spectra of naphthalene SOA as a function of increasing photochemical age in the PAM reactor. The sharp singlet at $0 \mathrm{ppm}$ represents the internal standard (TSP- $d_{4}$ ), while the broad peak at $4.8 \mathrm{ppm}$ is the - partly instrumentally suppressed - HDO peak.

respect to aromatics compared to SOA samples of smaller ageing state. Compared to $\alpha$-pinene SOA, the ${ }^{1} \mathrm{H}$-NMR fingerprint of naphthalene SOA appears less sensitive to variations in the $\mathrm{OH}$ exposure between the low and the medium level of exposure. More substantial changes can be found for the most oxidized sample, which are only partly visible due the low signal-to-noise ratio of the spectrum.

\subsection{3 ${ }^{1} \mathrm{H}$-NMR fingerprints of non-IEPOX isoprene SOA}

The samples of isoprene SOA were obtained from the same $\mathrm{OH}$ exposure (corresponding approximately to a "medium" exposure in the $\alpha$-pinene and naphthalene experiments) and differed only for collection time and sample quantity loaded on the filter. The isoprene SOA ${ }^{1} \mathrm{H}-\mathrm{NMR}$ spectra profiles were all very similar (an example is provided in Fig. 3). The comparison with literature data (Budisulistiorini et al., 2015) led to the unambiguous identification of 2-methyltetrols, clearly responsible for the two singlets at $1.12 \mathrm{ppm}$ (methylic $\mathrm{H}$ atoms of methylerythritol) and $1.13 \mathrm{ppm}$ (methylic $\mathrm{H}$ atoms of methylthreitol) and for a series of multiplets between 3.4 and $3.9 \mathrm{ppm}$. Methylerythritol is more abundant (60\% of the sum of the two, as an average between two samples extracted in water and three extracted in methanol) than methylthreitol. The spectra show the occurrence of only two diastereomers among the possible four ones (González et al., 2011), indicating that the formation of methyltetrols is stereoselective, as already proposed by Cash et al. (2016) on the basis of a theoretical analysis of the IEPOX chemistry, and in contrast with the conclusions of González et al. (2011), claiming that methyltetrols are produced in laboratory conditions only in racemic mixtures. The two methyltetrols account for $65 \%$ of the total ${ }^{1} \mathrm{H}$-NMR signal, the rest being characterized by broad background signal with very few sharp resonances, indicating that the isoprene SOA samples are composed mainly of methyltetrols together with a significant amount of mass composed of a very complex mixture of products. The unresolved background resonances are located below the peaks of the methyltetrols, suggesting that the complex mixtures (which can include also oligomeric species) encompass molecular species (or monomers) similar to methyltetrols (at least in their $\mathrm{C}-\mathrm{H}$ backbone). However, the range of chemical shifts of the background bands characterize molecular species with more electronegative groups (leading to more deshielded $\mathrm{H}$ atoms) than methyltetrols: the band of methylic protons extends to $1.7 \mathrm{ppm}$ (with respect to $1.12-1.13$ of methyltetrols) and the band of alkoxy groups (HC-O) extends to $4.3 \mathrm{ppm}$. The results of Liu et al. (2016), indicating that non-IEPOX isoprene SOA includes peroxide equivalents of methyltetrols, are in agreement with these findings. However, Riva et al. (2016) reported only perox- 


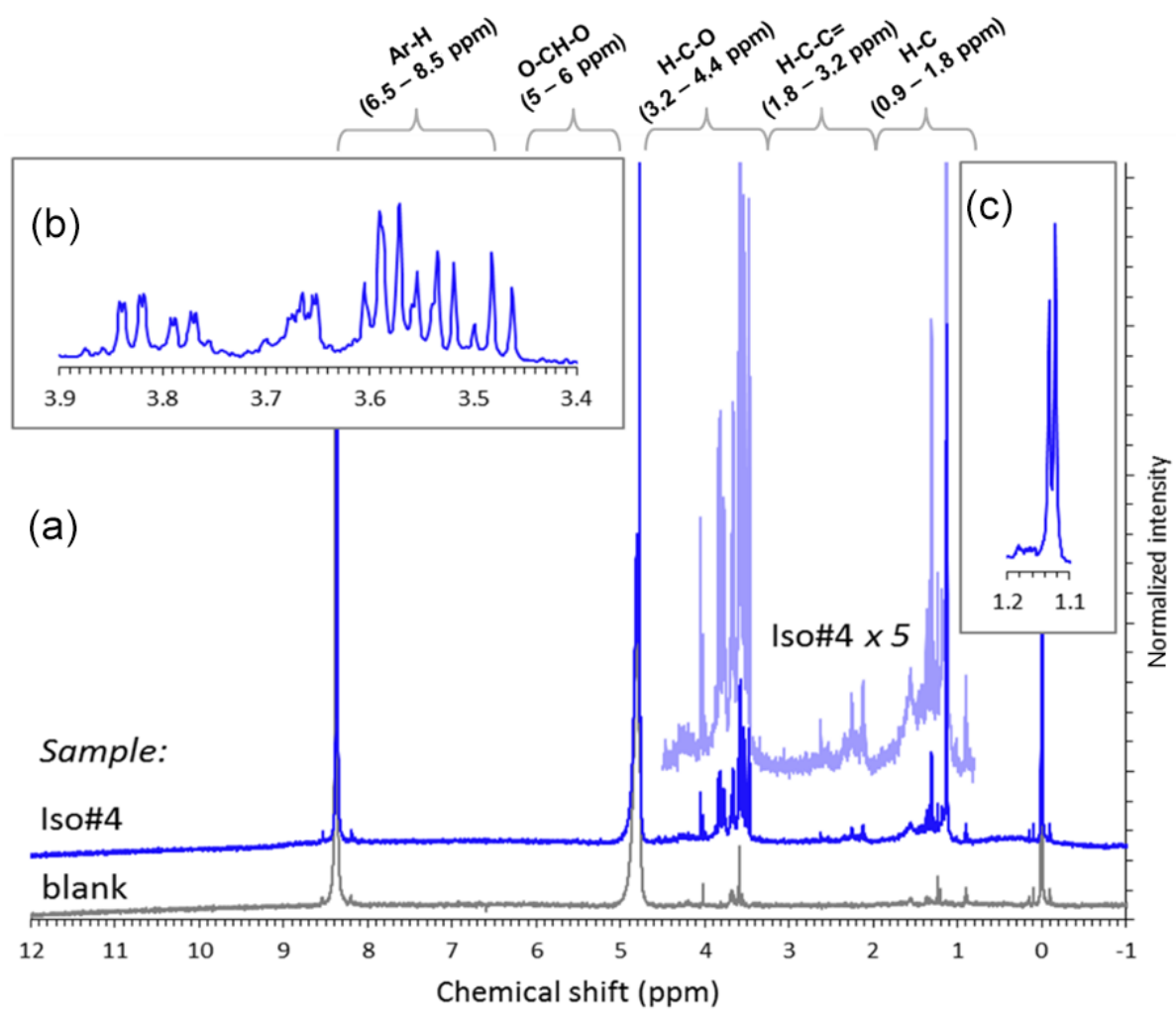

Figure 3. (a) ${ }^{1} \mathrm{H}-\mathrm{NMR}$ spectrum of isoprene SOA generated in the PAM reactor at an OH exposure of $8 \times 10^{11} \mathrm{molec}^{-3} \mathrm{~s}$. The bottom trace shows the same spectrum with enlarged the broad background bands. Panels (b) and (c) show the methyltetrols resonances between 3.4 and $3.9 \mathrm{ppm}$ and $1.12-1.13 \mathrm{ppm}$, respectively.

ides for non-IEPOX SOA in unseeded experiments and no methyltetrols. It is possible that peroxides decomposed to tetrols in our filter samples during collection downstream the PAM or afterwards during storing. The actual stability of isoprene hydroperoxides in the aerosol itself is largely uncertain; therefore the discrepancy between the findings presented in this study and the results of Riva et al. (2016) cannot be clarified at this stage. In addition, neither Liu et al. (2016) nor Riva et al. (2016) reported the presence of carboxylic or keto groups, while our data clearly indicate that these (and/or other acyl groups) are found in the unresolved mixtures of non-IEPOX isoprene SOA and are responsible for the signal band between 2.0 and $2.6 \mathrm{ppm}$. Still, this band is much less intense than that of alkoxyls, which is opposite to what observed for $\alpha$-pinene SOA, where acyls are by far the main oxygenated aliphatic functional group. Thus, ${ }^{1} \mathrm{H}-\mathrm{NMR}$ spectroscopy provides a distinct fingerprint for isoprene and monoterpene SOA.

\subsection{HPLC results}

The HPLC analysis of fresh $\alpha$-pinene SOA extracts shows the presence of compounds unretained by ion-exchange columns (neutral compounds) or weakly retained (monoand diacids) with a small contribution from compounds having a high retention factor (polyacids, PA, or HULIS), in agreement with previous results obtained from $\alpha$-pinene SOA samples generated in environmental chamber experiments (unpublished data). It should be noted, however, that the chromatographic analysis of SOA compounds in water extracts generally does not allow for recovery of highmolecular-weight organic oligomers susceptible to hydrolysis reactions (e.g., polyacetals; Kroll and Seinfeld, 2008). The HULIS determined by our method are essentially only the non-hydrolyzable ones, stable in aqueous solutions. The HULIS content increases only moderately with ageing, while the yield/fraction of diacids increases significantly with respect to monoacids and neutral/basic compounds (Fig. 4). With increasing photochemical age, the total organic carbon (TOC) mass fractions of monoacids, diacids and HULIS increase from 20 to $34 \%$ and 7 to $16 \%$, respectively, whereas the mass fraction of neutral compounds decreases from 19 to $9 \%$ (Fig. S3). These results are in qualitative agreement with the known chemistry of $\alpha$-pinene SOA, in which mono- and dicarboxylic acids are the most characteristic condensable first-generation products (Jenkin et al., 2000; Jaoui and Kamens, 2001), while tricarboxylic acids such as 3-methyl-1,2,3-butanetricarboxylic acid or pinyl-diaterpenyl ester (Szmigielski et al., 2007; Yasmeen et al., 2010) are 


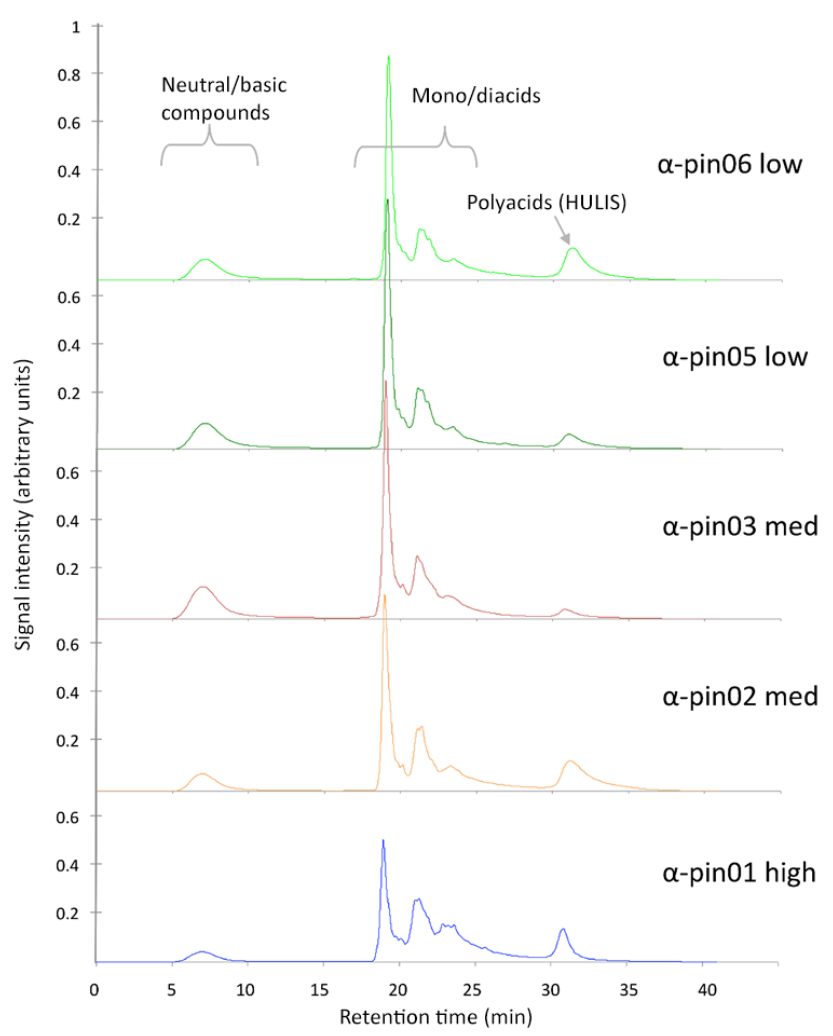

Figure 4. HPLC chromatograms of $\alpha$-pinene SOA water extracts. Chromatographic features are grouped into neutral, mono/dicarboxylic acid, and polycarboxylic acid classes based on their affinity for the column phase. Sample identifications are provided in Table 1.

present in lesser amounts and can contribute the observed concentrations of HULIS in this study.

The HPLC fractionation of naphthalene SOA (Fig. 5) shows that fresh samples are characterized by a mixture of neutral compounds and mono- and diacids, completely consistent with the molecular compositions reported in the literature (Lee and Lane, 2009). However, a net increase in acidic compounds with photochemical age can be clearly observed. However, the HULIS content, initially small, increases substantially and progressively with ageing. With increasing photochemical age, the TOC mass fraction of mono- and diacids decreases from 33 to $18 \%$ and from 34 to $33 \%$, respectively, while the fraction of PA/HULIS increases from 11 to $30 \%$ (Fig. S4). This is the first evidence of HULIS formation (determined with the ion-exchange method) in laboratory-generated SOA. The formation of polyacidic molecules with three or more carboxylic groups implies the opening of the second aromatic ring in the naphthalene precursor backbone, and/or oligomerization reactions. In both cases, products of such oxidation reactions cannot be explained by current naphthalene SOA molecular speciation studies (e.g., Kautzman et al., 2010).

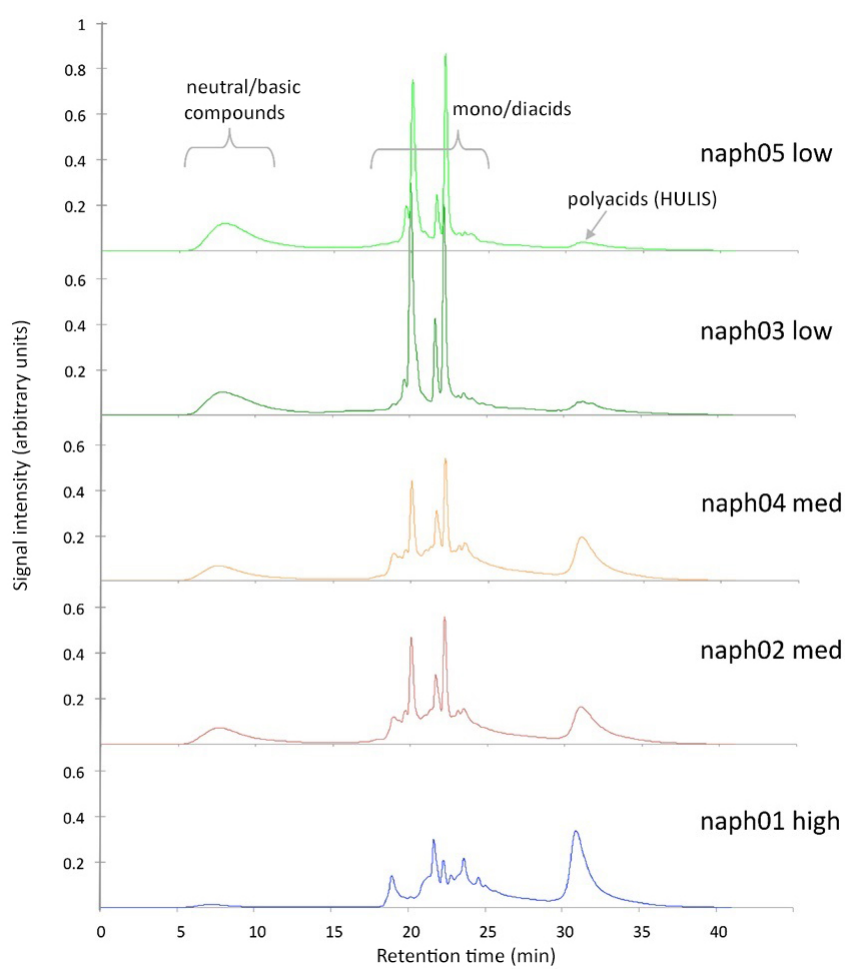

Figure 5. HPLC chromatograms of naphthalene SOA water extracts. Chromatographic features are grouped into neutral, mono/dicarboxylic acid, and polycarboxylic acid classes based on their affinity for the column phase. Sample identifications are provided in Table 1.

Finally, the HPLC analysis of isoprene SOA shows that neutral compounds (NCs) were dominant in all sample extracts (Fig. 6). NCs accounted for $59 \%$ of the TOC content of the sum of the HPLC fractions. The second most abundant fraction $(34 \%)$ is the monoacids, while diacids accounted for a much smaller fraction of TOC, and polyacids were almost absent (ca. $1 \%$ of the TOC). The dominance of NCs is consistent with the high yield methyltetrols and their analogues (see Sect. 3.1.3). Assuming that the distribution of ${ }^{1} \mathrm{H}-\mathrm{NMR}$ functional groups approximately reflects their carbon content, methyltetrols (accounting for $65 \%$ of the total ${ }^{1} \mathrm{H}-\mathrm{NMR}$ signal) can account for the whole of the HPLC neutral compounds and, as a corollary, the complex mixtures of products detected by unresolved bands by ${ }^{1} \mathrm{H}-\mathrm{NMR}$ spectroscopy correspond to the mono- and diacids in HPLC. As already noted in the previous section, the ${ }^{1} \mathrm{H}-\mathrm{NMR}$ analysis indeed shows the occurrence of acyl groups which indicate/support the presence of carboxylic acids. We cannot exclude, however, possible misclassification of some neutral compounds into the monoacid fraction, as already observed for some dicarbonyls (Decesari et al., 2005). It is worthwhile to clarify that the definition of chemical classes is based uniquely on the retention factor on the anion exchange and is therefore sensitive to chromatographic secondary interactions and 


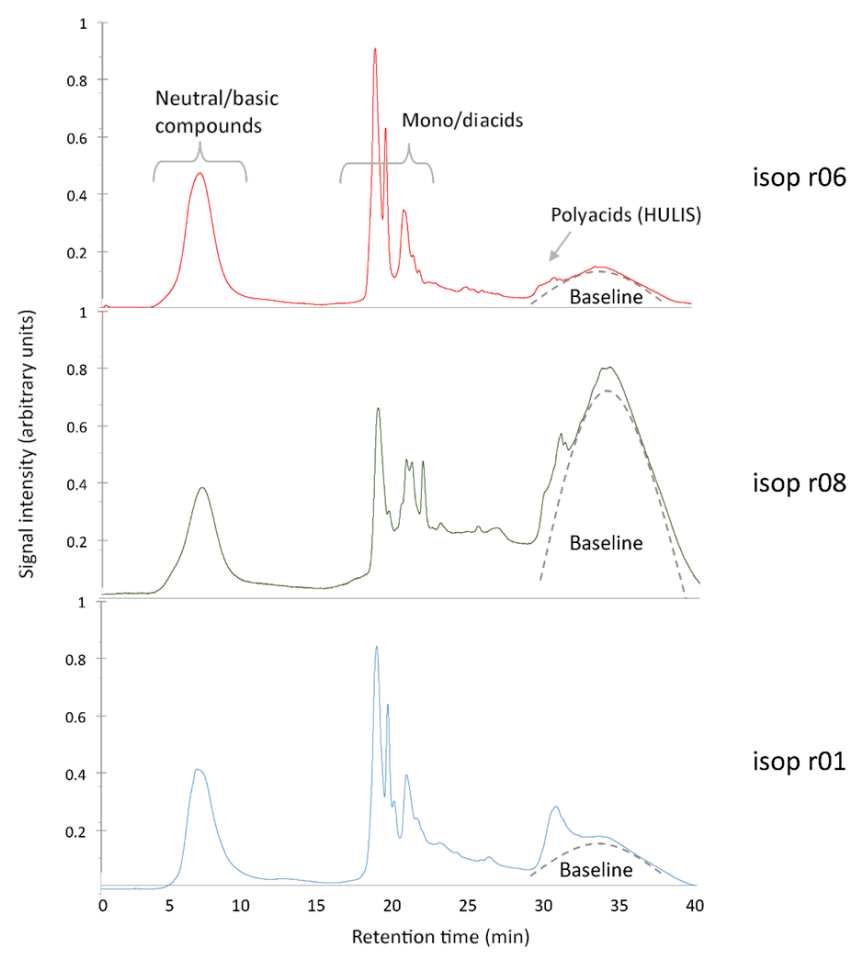

Figure 6. HPLC chromatograms of isoprene SOA water extracts. Chromatographic features are grouped into neutral, mono/dicarboxylic acid, and polycarboxylic acid classes based on their affinity for the column phase. Sample identifications are provided in Table 2.

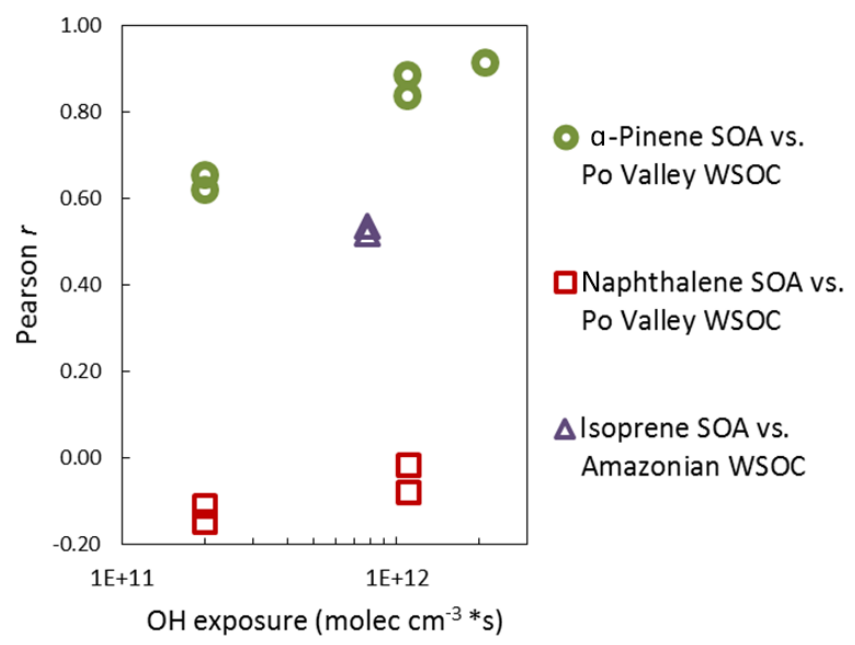

Figure 7. Pearson correlation coefficient between ${ }^{1} \mathrm{H}-\mathrm{NMR}$ spectra of PAM-generated SOA and ambient PEGASOS WSOC.

to chromatographic conditions. Such (unwanted) effects can explain the difference in speciation between samples Pin\#2 and Pin\#3, both obtained at medium oxidation state (Fig. S3). Pin\#3 was injected at significantly higher concentrations than the other samples (about 3 times than Pin\#2), which can have caused the elution of some acidic compounds along with the unretained NC fraction. The results of HPLC analysis of this particular sample are therefore excluded from the following discussion.

\section{Discussion and conclusions}

In this section, the ${ }^{1} \mathrm{H}-\mathrm{NMR}$ and HPLC results obtained for the isoprene, $\alpha$-pinene and naphthalene SOA systems are compared with ambient OA samples. First, we investigated the similarity between the ${ }^{1} \mathrm{H}-\mathrm{NMR}$ spectral profiles of SOA with those "typical" of ambient non-biomass-burning WSOC. For this purpose we used one sample of PM1 collected during the 2012 PEGASOS field campaign (Sandrini et al., 2016) in the rural Po Valley (Italy) which can be considered representative for a continental rural "near-city" site (according to the criteria of Putaud et al., 2010). A second PM1 sample was collected at a rural site in the State of Rondônia (Brazil) during the 2002 SMOCC field campaign, and, more precisely, during the early rainy season, when local biomass burning sources had largely ceased and the organic composition of submicron particles was dominated by biogenic emissions (Decesari et al. 2006; Tagliavini et al., 2006). The ambient WSOC and laboratory SOA spectra were binned to 400 points in order to remove the variability in chemical shifts due to, for example, different $\mathrm{pH}$ conditions during the analyses of the samples. Figure 7 shows the correlation between the SOA spectra and the reference spectra of ambient WSOC: the $\alpha$-pinene SOA and naphthalene SOA spectra were compared to the Po Valley WSOC sample, while the isoprene SOA spectra were compared to the Amazonian sample. There is good correlation $(0.62<r<0.92)$ between the ${ }^{1} \mathrm{H}$-NMR spectra of $\alpha$-pinene SOA, at all oxidation levels, with the spectrum of the Po Valley PM1 sample. This finding is in line with modeling results and previous experimental findings indicating that the organic composition in northern Italy in the summertime is dominated by biogenic SOA (Bessagnet et al., 2008; Gilardoni et al., 2011). A moderate positive correlation was also found between the spectra of isoprene SOA and of the PM1 sample from rural Brazil $(r=0.52,0.54)$. It should be noted that the relative humidity at this pasture site is variable during the day and very high overnight during the rainy season, based on the meteorological data presented by Betts et al. (2009). Therefore, biogenic aerosols are expected to include also isoprene SOA forming through the IEPOX route (Hu et al., 2015), which is not accounted for by our laboratory experiments. Finally, the naphthalene SOA spectra exhibit zero or negative correlations with the Po Valley WSOC spectrum $(-0.15<r<-0.02)$. This result is somewhat expected if we consider that ambient water-soluble aerosols are characterized by acyl functional groups $(\mathrm{HC}-\mathrm{C}=\mathrm{O})$ in higher concentrations with respect to alkoxy groups (HC-O) and by a smaller aromatic content (Decesari et al., 2007), with a functional group pattern that is well reproduced by 

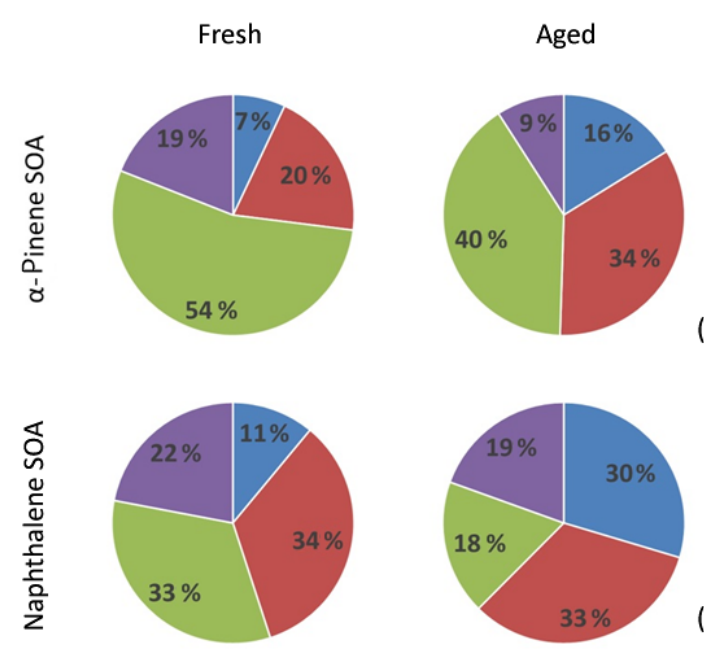

(a)

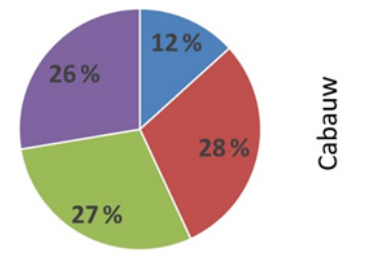

(b)

Figure 8. Distribution of HPLC fractions (total recovered TOC content $=100 \%$ ) for $\alpha$-pinene SOA (a), naphthalene (b), and for ambient OA sampled in Cabauw, Netherlands (c).

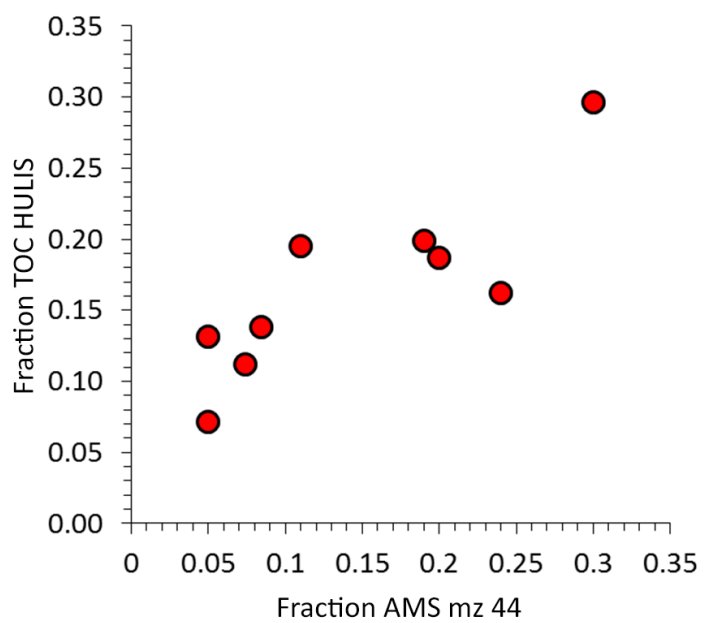

Figure 9. Correlation plot between the AMS f44 of SOA and the HULIS fraction of HPLC-eluted WSOC.

$\alpha$-pinene SOA and not by naphthalene SOA. Clearly, naphthalene SOA alone, with a hydrogen-to-carbon $(\mathrm{H} / \mathrm{C})$ ratio less than 0.9 due to relatively high aromatic content (Lambe et al. 2011, 2015), does not mimic ambient OA bulk composition. It should be noted, however, that naphthalene and other polyaromatic hydrocarbons are co-emitted with many other anthropogenic IVOCs and VOCs, including aliphatic compounds in the real atmosphere; therefore the contribution of naphthalene SOA could be simply masked by the contribution of aliphatic IVOC SOA in the ${ }^{1} \mathrm{H}-\mathrm{NMR}$ spectra of ambient WSOC. When limiting the correlation analysis of Fig. 7 to the aromatic and vinyl region of the spectra (>6 ppm), Pearson $r$ coefficients of 0.49 to 0.58 are found between the naphthalene SOA and the ambient WSOC spectra, while small values (between -0.2 and 0.4 ) are found for the $\alpha$-pinene and isoprene SOA. This result suggests that SOA produced from naphthalene or similar precursors, including many other ring-retaining oxidation products (Sect. 3.1.2), can explain the presence of aromatic moieties in ambient water-soluble aerosols in areas not affected by biomass burning emissions.

When considering the full spectral range, the ${ }^{1} \mathrm{H}-\mathrm{NMR}$ spectra of $\alpha$-pinene SOA most closely mimic the functional group distributions of the ambient WSOC sample obtained in PEGASOS (Fig. S1). Interestingly, similarity between ${ }^{1} \mathrm{H}-$ NMR spectra of $\alpha$-pinene SOA and Po Valley WSOC increases with increasing photochemical age. For the most oxidized $\alpha$-pinene SOA samples, the functional group composition, characterized by polysubstituted aliphatic compounds rich of acyls (carboxylic or keto groups), overlaps well with that of ambient WSOC. A good fit between $\alpha$-pinene SOA and ambient WSOC mass spectral features is already achieved at medium oxidation conditions, in agreement with the results of Lambe et al. (2011), showing that the correlation between the AMS spectra of PAM-generated $\alpha$-pinene SOA with the spectra of ambient oxygenated OA (OOA) increases up to an exposure of $1 \times 10^{12} \mathrm{OH}$ molec $\mathrm{cm}^{-3} \times \mathrm{s}$ and remains rather stable afterwards. These results suggest that ${ }^{1} \mathrm{H}$-NMR-traced ageing processes reflect the same chemical mechanisms already studied using high-resolution AMS techniques. However, the correlation coefficients shown in Fig. 7 for the ${ }^{1} \mathrm{H}$-NMR spectra of $\alpha$-pinene vs. ambient WSOC $\left(r^{2}=0.39\right.$ to 0.84$)$ are smaller than those between the HR-ToF-AMS spectra of PAM-generated SOA vs. ambient OOA ( $r^{2}=0.7$ to 0.9 ) (Fig. 9 in Lambe et al., 2011). Apparently, the AMS features of ambient OA are more easily reproduced by PAM experiments than the ${ }^{1} \mathrm{H}-\mathrm{NMR}$ composition, or, in other words, ${ }^{1} \mathrm{H}-\mathrm{NMR}$ spectroscopy exhibits a greater selectivity for the OA components than AMS. Specifically, ${ }^{1} \mathrm{H}-\mathrm{NMR}$ spectroscopy was able to resolve significant 
changes in composition of $\alpha$-pinene SOA with photochemical ageing in great detail, especially at an $\mathrm{OH}$ exposure of $\sim 1.1 \times 10^{12}$ molec $\mathrm{OH} \mathrm{cm}^{-3}$ s equivalent to multiple days of atmospheric ageing. It should be noted, finally, that a comparison of the AMS and ${ }^{1} \mathrm{H}-\mathrm{NMR}$ techniques with respect to their ability to trace chemical ageing in laboratory SOA and ambient oxidized aerosols is challenged by the incomplete overlap between the classes of organic compounds contributing to OOA and to WSOC (Xu et al., 2017).

A comparison of fresh and aged SOA with ambient WSOC samples with respect to the HPLC fraction distributions is reported in Fig. 8. The distribution of neutral vs. acidic classes of compounds in ambient WSOC refers to the average of the samples collected at the rural background station of Cabauw in the Netherlands (Paglione et al., 2014b). The station is located downwind from anthropogenic sources and biogenic emissions (terpenes from deciduous forests) over a large sector of northwest Europe (Henne et al., 2010). The HULIS contribution in these samples varied between 15 and $20 \%$, in line with previous results obtained in the Po Valley (Mancinelli et al., 2007), but lower than in biomass burning aerosol samples (Decesari et al., 2006). The $\alpha$-pinene SOA generated in the PAM reactor at high photochemical age and the fresh naphthalene SOA are characterized by a HULIS amount similar to that of Cabauw samples, while the polyacidic content of aged naphthalene SOA is higher than in the ambient samples. In the real atmosphere, naphthalene is coemitted with many other reactive VOC and IVOC with potentially very diverse HULIS formation yields; therefore, the results presented in Fig. 8 do not necessarily mean that the chemical composition of ambient OA in Cabauw is better described by the monoterpene chemistry rather than by anthropogenic IVOC oxidation. On the other hand, these results demonstrate that laboratory experiments of SOA formation can generate complex mixtures of products with the same chromatographic properties of HULIS provided a sufficient extent of photochemical ageing using the PAM reactor or related techniques. The HULIS fraction of WSOC is in fact proportional to the AMS $\mathrm{f} 44$ for SOA (integrated over the filter sampling times) (Fig. 9) irrespective of precursor type. Therefore, the formation of polycarboxylic acids determined by the HPLC technique follows the same positive trend in concentrations of the AMS proxy for $\mathrm{C}(\mathrm{O}) \mathrm{OH}$ groups with increasing $\mathrm{OH}$ exposure. This is in contrast with the numerous observations of rapid formation of SOA oligomers during reaction chamber experiments (Kalberer et al., 2006; Reemtsma et al., 2006), indicating that oligomers do not account for chromatographically defined HULIS. A survey of the laboratory studies on the formation of humic material in secondary aerosol shows that evidence for the formation of polycarboxylic acids comes from the reaction of phenolic compounds in the presence of particulate water (Hoffer et al., 2004), while little is known for unseeded, dry gas-to-particle formation experiments. With the exception of the very preliminary data reported by Baltensperger et al. (2008), our results - to our best knowledge - are the first showing the occurrence of HULIS sensu stricto in monoterpene and aromatic hydrocarbon SOA, and these HULIS are clearly shown to be a product of photochemical ageing.

In conclusion, we observed that OA ageing reactions in the PAM reactor produces water-soluble compounds of high complexity but with spectroscopic and chromatographic properties that converge towards those characteristic of ambient OA. Specifically, a good correlation between ambient HPLC $/{ }^{1} \mathrm{H}$-NMR samples and aged $\alpha$-pinene SOA was observed in respect to HULIS content and ${ }^{1} \mathrm{H}$-NMR functional group distribution, while aged aromatic IVOC SOA shows clear potential for HULIS formation. The isoprene SOA samples do not show compositional features with a clear overlap with those of ambient WSOC obtained in the Cabauw and Po Valley samples that are representative of continental polluted atmospheres, but they should serve as useful reference spectra for future studies/environments impacted by non-IEPOX isoprene SOA.

Data availability. All spectroscopic (NMR) and chromatographic data are available upon request from the first author.

\section{The Supplement related to this article is available online at https://doi.org/10.5194/acp-17-10405-2017- supplement.}

Competing interests. The authors declare that they have no conflict of interest.

Acknowledgements. Andrew T. Lambe and Paola Massoli acknowledge support by the Atmospheric Chemistry Program of the US National Science Foundation under grants AGS-1536939, AGS-1537446 and by the US Office of Science (BER), Department of Energy (Atmospheric Systems Research), under grants DESC0006980 and DE-SC0011935. We thank Manjula Canagaratna (ARI), Douglas Worsnop (ARI), Timothy Onasch (BC/ARI) and Paul Davidovits (BC) for helpful discussions. Stefano Decesari, Stefania Gilardoni, Marco Paglione and Nicola Zanca acknowledge funding from the European FP7 project BACCHUS (grant agreement no. 49990 603445). Fabio Moretti, formerly at the Department of Chemistry of the University of Bologna, and Andrea Mazzanti and Alessandra Petroli of the Department of Industrial Chemistry of the University of Bologna are also greatly acknowledged for support with the ${ }^{1} \mathrm{H}-\mathrm{NMR}$ analyses.

Edited by: James B. Burkholder

Reviewed by: two anonymous referees

\section{References}

Baduel, C., Voisin, D., and Jaffrezo, J. L.: Comparison of analytical methods for Humic Like Substances (HULIS) measurements 
in atmospheric particles, Atmos. Chem. Phys., 9, 5949-5962, https://doi.org/10.5194/acp-9-5949-2009, 2009.

Bahreini, R., Middlebrook, A. M., Brock, C. A., de Gouw, J. A., McKeen, S. A., Williams, L. R., Daumit, K. E., Lambe, A. T., Massoli, P., Canagaratna, M. R., Ahmadov, R., Carrasquillo, A. J., Cross, E. S., Ervens, B., Holloway, J. S., Hunter, J. F., Onasch, T. B., Pollack, I. B., Roberts, J. M., Ryerson, T. B., Warneke, C., Davidovits, P., Worsnop, D. R., and Kroll, J. H.: Mass Spectral Analysis of Organic Aerosol Formed Downwind of the Deepwater Horizon Oil Spill: Field Studies and Laboratory Confirmations, Environ. Sci. Technol., 46, 8025-8034, https://doi.org/10.1021/es301691k, 2012.

Baltensperger, U., Dommen, J., Alfarra, M. R., Duplissy, J., Gaeggeler, K., Metzger, A., Facchini, M. C., Decesari, S., Finessi, E., Reinnig, C., Schott, M., Warnke, J., Hoffmann, T., Klatzer, B., Puxbaum, H., Geiser, M., Savi, M., Lang, D., Kalberer, M., and Geiser, T.: Combined determination of the chemical composition and of health effects of secondary organic aerosols: the POLYSOA project, J. Aerosol Med Pulm Drug Deliv., 21, 145-154, 2008.

Bessagnet, B., Menut, L., Curci, G., Hodzic, A., Guillaume, B., Liousse, C., Moukhtar, S., Pun, B., Seigneur, C., and Schulz, M.: Regional modeling of carbonaceous aerosols over Europe - focus on secondary organic aerosols, J. Atmos. Chem., 61, 175-202, 2008.

Betts, A. K., Fisch, G., von Randow, C., Silva Dias, M. A. F., Cohen, J. C. P., da Silva, R., and Fitzjarrald, D. R.: The Amazonian boundary layer and mesoscale circulations, in: Amazonia and Global Change, American Geophysical Union, ISBN: 9780875904764, 163-181, 2009.

Bones, D. L., Henricksen, D. K., Mang, S. A., Gonsior, M., Bateman, A. P., Nguyen, T. B., Cooper, W. J., and Nizkorodov, S. A.: Appearance of strong absorbers and fluorophores in limonene$\mathrm{O}_{3}$ secondary organic aerosol due to $\mathrm{NH}_{4}^{+}-$mediated chemical aging over long time scales, J. Geophys. Res., 115, 1-14, https://doi.org/10.1029/2009JD012864, 2010.

Bruns, E. A., El Haddad, I., Keller, A., Klein, F., Kumar, N. K., Pieber, S. M., Corbin, J. C., Slowik, J. G., Brune, W. H., Baltensperger, U., and Prévôt, A. S. H.: Inter-comparison of laboratory smog chamber and flow reactor systems on organic aerosol yield and composition, Atmos. Meas. Tech., 8, 23152332, https://doi.org/10.5194/amt-8-2315-2015, 2015.

Budisulistiorini, S. H., Li, X., Bairai, S. T., Renfro, J., Liu, Y., Liu, Y. J., McKinney, K. A., Martin, S. T., McNeill, V. F., Pye, H. O. T., Nenes, A., Neff, M. E., Stone, E. A., Mueller, S., Knote, C., Shaw, S. L., Zhang, Z., Gold, A., and Surratt, J. D.: Examining the effects of anthropogenic emissions on isoprenederived secondary organic aerosol formation during the 2013 Southern Oxidant and Aerosol Study (SOAS) at the Look Rock, Tennessee ground site, Atmos. Chem. Phys., 15, 8871-8888, https://doi.org/10.5194/acp-15-8871-2015, 2015.

Cash, J. M., Heal, M. R., Langford, B., and Drewer, J.: A review of stereochemical implications in the generation of secondary organic aerosol from isoprene oxidation, Environ. Sci., 18, 13691380, 2016.

Cavalli, F., Facchini, M. C., Decesari, S., Emblico, L., Mircea, M., Jensen, N. R., and Fuzzi, S.: Size-segregated aerosol chemical composition at a boreal site in southern Finland, dur- ing the QUEST project, Atmos. Chem. Phys., 6, 993-1002, https://doi.org/10.5194/acp-6-993-2006, 2006.

Chacon-Madrid, H. J. and Donahue, N. M.: Fragmentation vs. functionalization: chemical aging and organic aerosol formation, Atmos. Chem. Phys., 11, 10553-10563, https://doi.org/10.5194/acp-11-10553-2011, 2011.

Chhabra, P. S., Lambe, A. T., Canagaratna, M. R., Stark, H., Jayne, J. T., Onasch, T. B., Davidovits, P., Kimmel, J. R., and Worsnop, D. R.: Application of high-resolution time-of-flight chemical ionization mass spectrometry measurements to estimate volatility distributions of $\alpha$-pinene and naphthalene oxidation products, Atmos. Meas. Tech., 8, 1-18, https://doi.org/10.5194/amt-8-12015, 2015.

Claeys, M., Graham, B., Vas, G., Wang, W., Vermeylen, R., Pashynska, V., Cafmeyer, J., Guyon, P., Andreae, M. O., Artaxo, P., and Maenhaut, W.: Formation of secondary organic aerosols through photooxidation of isoprene, Science, 303, 1173, https://doi.org/10.1126/science.1092805, 2004.

Decesari, S., Facchini, M. C., Fuzzi S., and Tagliavini, E.: Characterization of water-soluble organic compounds in atmospheric aerosol: A new approach, J. Geophys. Res., 105, 1481-1489, 2000.

Decesari, S., Moretti, F., Fuzzi, S., Facchini, M. C., and Tagliavini, E.: Comment on "On the use of anion exchange chromatography for the characterization of water soluble organic carbon" by H. Chang et al., Geophys. Res. Lett., 32, 1-3, https://doi.org/10.1029/2005GL023826, 2005.

Decesari, S., Fuzzi, S., Facchini, M. C., Mircea, M., Emblico, L., Cavalli, F., Maenhaut, W., Chi, X., Schkolnik, G., Falkovich, A., Rudich, Y., Claeys, M., Pashynska, V., Vas, G., Kourtchev, I., Vermeylen, R., Hoffer, A., Andreae, M. O., Tagliavini, E., Moretti, F., and Artaxo, P.: Characterization of the organic composition of aerosols from Rondônia, Brazil, during the LBA-SMOCC 2002 experiment and its representation through model compounds, Atmos. Chem. Phys., 6, 375-402, https://doi.org/10.5194/acp-6-375-2006, 2006.

Decesari, S., Mircea, M., Cavalli, F., Fuzzi, S., Moretti, F., Tagliavini, E., and Facchini, M. C.: Source Attribution of WaterSoluble Organic Aerosol by Nuclear Magnetic Resonance Spectroscopy, Environ. Sci. Technol., 41, 2479-2484, 2007.

Ehn, M., Kleist, E., Junninen, H., Petäjä, T., Lönn, G., Schobesberger, S., Dal Maso, M., Trimborn, A., Kulmala, M., Worsnop, D. R., Wahner, A., Wildt, J., and Mentel, Th. F.: Gas phase formation of extremely oxidized pinene reaction products in chamber and ambient air, Atmos. Chem. Phys., 12, 5113-5127, https://doi.org/10.5194/acp-12-5113-2012, 2012.

Finessi, E., Lidster, R. T., Whiting, F., Elliott, T., Alfarra, M. R., McFiggans, G. B., and Hamilton, J. F.: Improving the quantification of secondary organic aerosol using a microflow reactor coupled to HPLC-MS and NMR to manufacture ad hoc calibration standards, Anal. Chem., 86, 11238-11245, 2014.

Gilardoni, S., Vignati, E., Cavalli, F., Putaud, J. P., Larsen, B. R., Karl, M., Stenström, K., Genberg, J., Henne, S., and Dentener, F.: Better constraints on sources of carbonaceous aerosols using a combined ${ }^{14} \mathrm{C}$ - macro tracer analysis in a European rural background site, Atmos. Chem. Phys., 11, 5685-5700, https://doi.org/10.5194/acp-11-5685-2011, 2011.

González, N. J. D., Borg-Karlson, A.-K., Pettersson Redeby, J., Nozière, B., Krejci, R., Peib, Y., Dommen, J., and Prévôt, A. S. 
H.: New method for resolving the enantiomeric composition of 2-methyltetrols in atmospheric organic aerosols, J. Chromatogr. A, 1218, 9288-9294, 2011.

Graber, E. R. and Rudich, Y.: Atmospheric HULIS: How humiclike are they? A comprehensive and critical review, Atmos. Chem. Phys., 6, 729-753, https://doi.org/10.5194/acp-6-7292006, 2006.

Guenther, A., Hewitt, C. N., Erickson, D., Fall, R., Geron, C., Graedel, T., Harley, P., Klinger, L., Lerdau, M., Mckay, W. A., Pierce, T., Scholes, B., Steinbrecher, R., Tallamraju, R., Taylor, J., and Zimmerman, P.: A global model of natural volatile organic compound emissions, J. Geophys. Res., 100, 8873-8892, https://doi.org/10.1029/94JD02950, 1995.

Hall IV, W. A., Pennington, M. R., and Johnston, M. V.: Molecular transformations accompanying the aging of laboratory secondary organic aerosol, Environ. Sci. Technol., 47, 2230-2237, 2013.

Hallquist, M., Wenger, J. C., Baltensperger, U., Rudich, Y., Simpson, D., Claeys, M., Dommen, J., Donahue, N. M., George, C., Goldstein, A. H., Hamilton, J. F., Herrmann, H., Hoffmann, T., Iinuma, Y., Jang, M., Jenkin, M. E., Jimenez, J. L., Kiendler-Scharr, A., Maenhaut, W., McFiggans, G., Mentel, Th. F., Monod, A., Prévôt, A. S. H., Seinfeld, J. H., Surratt, J. D., Szmigielski, R., and Wildt, J.: The formation, properties and impact of secondary organic aerosol: current and emerging issues, Atmos. Chem. Phys., 9, 5155-5236, https://doi.org/10.5194/acp9-5155-2009, 2009.

Havers, N., Burba, P., Lambertm, J., and Klockow, D.: Spectroscopic characterization of humic-like substances in airborne particulate matter, J. Atmos. Chem., 29, 45-54, 1998.

Heald, C. L., Jacob, D. J., Park, R. J., Russell, L. M., Huebert, B. J., Seinfeld, J. H., Liao, H., and Weber, R. J.: A large organic aerosol source in the free troposphere missing from current models, Geophys. Res. Lett., 32, L18809, https://doi.org/10.1029/2005GL023831, 2005.

Henne, S., Brunner, D., Folini, D., Solberg, S., Klausen, J., and Buchmann, B.: Assessment of parameters describing representativeness of air quality in-situ measurement sites, Atmos. Chem. Phys., 10, 3561-3581, https://doi.org/10.5194/acp-103561-2010, 2010.

Hodzic, A., Kasibhatla, P. S., Jo, D. S., Cappa, C. D., Jimenez, J. L., Madronich, S., and Park, R. J.: Rethinking the global secondary organic aerosol (SOA) budget: stronger production, faster removal, shorter lifetime, Atmos. Chem. Phys., 16, 7917-7941, https://doi.org/10.5194/acp-16-7917-2016, 2016.

Hoffer, A., Kiss, G., Blazso, M., and Gelencsér, A.: Chemical characterization of humic-like substances (HULIS) formed from a lignin-type precursor in model cloud water, Geophys. Res. Lett., 31, L06115, https://doi.org/10.1029/2003GL018962, 2004.

Hu, W. W., Campuzano-Jost, P., Palm, B. B., Day, D. A., Ortega, A. M., Hayes, P. L., Krechmer, J. E., Chen, Q., Kuwata, M., Liu, Y. J., de Sá, S. S., McKinney, K., Martin, S. T., Hu, M., Budisulistiorini, S. H., Riva, M., Surratt, J. D., St. Clair, J. M., Isaacman-Van Wertz, G., Yee, L. D., Goldstein, A. H., Carbone, S., Brito, J., Artaxo, P., de Gouw, J. A., Koss, A., Wisthaler, A., Mikoviny, T., Karl, T., Kaser, L., Jud, W., Hansel, A., Docherty, K. S., Alexander, M. L., Robinson, N. H., Coe, H., Allan, J. D., Canagaratna, M. R., Paulot, F., and Jimenez, J. L.: Characterization of a real-time tracer for isoprene epoxydiols-derived secondary organic aerosol (IEPOX-SOA) from aerosol mass spec- trometer measurements, Atmos. Chem. Phys., 15, 11807-11833, https://doi.org/10.5194/acp-15-11807-2015, 2015.

Jaoui, M. and Kamens, R. M.: Mass balance of gaseous and particulate products analysis from $\alpha$-pinene/ $\mathrm{NO}_{X} /$ air in the presence of natural sunlight, J. Geophys. Res., 106, 12541-12558, 2001.

Jathar, S. H., Friedman, B., Galang, A. A., Link, M. F., Brophy, P., Volckens, J., Eluri, S., and Farmer, D. K.: Linking Load, Fuel, and Emission Controls to Photochemical Production of Secondary Organic Aerosol from a Diesel Engine, Environ. Sci. Technol., 51, 1377-1386, https://doi.org/10.1021/acs.est.6b04602, 2017.

Jenkin, M. E., Shallcross, D. E., and Harvey, J. N.: Development and application of a possible mechanism for the generation of cis-pinic acid from the ozonolysis of $\alpha$ - and $\beta$-pinene, Atmos. Environ., 34, 2837-2850, 2000.

Jimenez, J. L., Canagaratna, M. R., Donahue, N. M., Prevot, A. S. H., Zhang, Q., Kroll, J. H., DeCarlo, P. F., Allan, J. D., Coe, H., Ng, N. L., Aiken, A. C., Docherty, K. S., Ulbrich, I. M., Grieshop, A. P., Robinson, A. L., Duplissy, J., Smith, J. D., Wilson, K. R., Lanz, V. A., Hueglin, C., Sun, Y. L., Tian, J., Laaksonen, A., Raatikainen, T., Rautiainen, J., Vaattovaara, P., Ehn, M., Kulmala, M., Tomlinson, J. M., Collins, D. R., Cubison, M. J., Dunlea, E. J., Huffman, J. A., Onasch, T. B., Alfarra, M. R., Williams, P. I., Bower, K., Kondo, Y., Schneider, J., Drewnick, F., Borrmann, S., Weimer, S., Demerjian, K., Salcedo, D., Cottrell, L., Griffin, R., Takami, A., Miyoshi, T., Hatakeyama, S., Shimono, A., Sun, J. Y., Zhang, Y. M., Dzepina, K., Kimmel, J. R., Sueper, D., Jayne, J. T., Herndon, S. C., Trimborn, A. M., Williams, L. R., Wood, E. C., Middlebrook, A. M., Kolb, C. E., Baltensperger, U., and Worsnop, D. R.: Evolution of Organic Aerosols in the Atmosphere, Science, 326, 1525-1528, https://doi.org/10.1126/science.1180353, 2009.

Kalberer, M., Sax, M., and Samburova, V.: Molecular size evolution of oligomers in organic aerosols collected in urban atmospheres and generated in a smog chamber, Environ. Sci. Technol., 40, 5917-5922, 2006.

Kang, E., Root, M. J., Toohey, D. W., and Brune, W. H.: Introducing the concept of Potential Aerosol Mass (PAM), Atmos. Chem. Phys., 7, 5727-5744, https://doi.org/10.5194/acp-7-5727-2007, 2007.

Kautzman, K. E., Surratt, J. D., Chan, M. N., Chan, A. W. H., Hersey, S. P., Chhabra, P. S., Dalleska, N. F., Wennberg, P. O., Flagan R. C., and Seinfeld, J. H.: Chemical composition of gasand aerosol-phase products from the photooxidation of naphthalene, J. Phys. Chem. A, 114, 913-934, 2010.

Keller, A. and Burtscher, H.: A continuous photo-oxidation flow reactor for a defined measurement of the SOA formation potential of wood burning emissions, J. Aerosol Sci., 49, 9-20, 2012.

Krechmer, J. E., Coggon, M. M., Massoli, P., Nguyen, T. B., Crounse, J. D., Hu, W., Day, D. A., Tyndall, G. S., Henze, D. K., Rivera-Rios, J. C., Nowak, J. B., Kimmel, J. R., Mauldin, R. L., Stark, H., Jayne, J. T., Sipilä, M., Junninen, H., Clair, J. M. St., Zhang, X., Feiner, P. A., Zhang, L., Miller, D. O., Brune, W. H., Keutsch, F. N., Wennberg, P. O., Seinfeld, J. H., Worsnop, D. R., Jimenez, J. L., and Canagaratna, M. R.: Formation of Low Volatility Organic Compounds and Secondary Organic Aerosol from Isoprene Hydroxyhydroperoxide Low-NO Oxidation, Environ. Sci. Technol. 49, 10330-10339, 2015. 
Krechmer, J. E., Pagonis, D., Ziemann, P. J., and Jimenez, J. L.: Quantification of Gas-Wall Partitioning in Teflon Environmental Chambers Using Rapid Bursts of Low-Volatility Oxidized Species Generated in Situ, Environ. Sci. Technol., 50, 57575765, https://doi.org/10.1021/acs.est.6b00606, 2016.

Kroll, J. H. and Seinfeld, J. H.: Chemistry of secondary organic aerosol: Formation and evolution of low-volatility organics in the atmosphere, Atmos. Environ., 42, 3593-3624, 2008.

Kroll, J. H., Smith, J. D., Che, D. L., Kessler, S. H., Worsnop, D. R., and Wilson, K. R.: Measurement of fragmentation and functionalization pathways in the heterogeneous oxidation of oxidized organic aerosol, Phys. Chem. Chem. Phys., 11, 8005-8014, 2009.

Lambe, A. T., Ahern, A. T., Williams, L. R., Slowik, J. G., Wong, J. P. S., Abbatt, J. P. D., Brune, W. H., Ng, N. L., Wright, J. P., Croasdale, D. R., Worsnop, D. R., Davidovits, P., and Onasch, T. B.: Characterization of aerosol photooxidation flow reactors: heterogeneous oxidation, secondary organic aerosol formation and cloud condensation nuclei activity measurements, Atmos. Meas. Tech., 4, 445-461, https://doi.org/10.5194/amt-4445-2011, 2011.

Lambe, A. T., Onasch, T. B., Croasdale, D. R., Wright, J. P., Martin, A. T., Franklin, J. P., Massoli, P., Kroll, J. H., Canagaratna, M. R., Brune, W. H., Wornsop, D. R., and Davidovits, P.: Transitions from functionalization to fragmentation reactions of secondary organic aerosol (SOA) generated from the laboratory $\mathrm{OH}$ oxidation of alkane precursors, Environ. Sci. Technol., 46, 5430-5437, 2012.

Lambe, A. T., Chhabra, P. S., Onasch, T. B., Brune, W. H., Hunter, J. F., Kroll, J. H., Cummings, M. J., Brogan, J. F., Parmar, Y., Worsnop, D. R., Kolb, C. E., and Davidovits, P.: Effect of oxidant concentration, exposure time, and seed particles on secondary organic aerosol chemical composition and yield, Atmos. Chem. Phys., 15, 3063-3075, https://doi.org/10.5194/acp15-3063-2015, 2015.

Lee, J. Y. and Lane, D. A.: Unique products from the reaction of naphthalene with the hydroxyl radical, Atmos. Environ., 43, 4886-4893, 2009.

Li, R., Palm, B. B., Ortega, A. M., Hlywiak, J., Hu, W., Peng, Z., Day, D. A., Knote, C., Brune, W. H., de Gouw, J. A., and Jimenez, J. L.: Modeling the Radical Chemistry in an Oxidation Flow Reactor: Radical Formation and Recycling, Sensitivities, and the $\mathrm{OH}$ Exposure Estimation Equation, J. Phys. Chem. A, 119, 4418-4432, 2015.

Limbeck, A., Kulmala, M., and Puxbaum, H.: Secondary organic aerosol formation in the atmosphere via heterogeneous reaction of gaseous isoprene on acidic particles, Geophys. Res. Lett., 30, 1-4, https://doi.org/10.1029/2003GL017738, 2003.

Lin, Y.-H., Zhang, Z., Docherty, K. S., Zhang, H., Budisulistiorini, S. H., Rubitschun, C. L., Shaw, S. L., Knipping, E. M., Edgerton, E. S., Kleindienst, T. E., Gold, A., and Surratt, J. D.: Isoprene Epoxydiols as Precursors to Secondary Organic Aerosol Formation: Acid-Catalyzed Reactive Uptake Studies with Authentic Compounds, Environ. Sci. Technol., 46, 250-258, 2012.

Liu, J., D’Ambro, E. L., Lee, B. H., Lopez-Hilfiker, F. D., Zaveri, R. A., Rivera-Rios, J. C., Keutsch, F. N., Iyer, S., Kurten, T., Zhang, Z., Gold, A., Surratt, J. D., Shilling, J. E., and Thornton, J. A.: Efficient Isoprene Secondary Organic Aerosol Formation from a Non-IEPOX Pathway, Environ. Sci. Technol., 50, 9872-9880, 2016.
Mancinelli, V., Rinaldi, M., Finessi, E., Emblico, L., Mircea, M. Fuzzi, S., Facchini, M. C., and Decesari, S.: An anion-exchange high-performance liquid chromatography method coupled to total organic carbon determination for the analysis of water-soluble organic aerosols, J. Chrom., 1149, 385-389, 2007.

Mao, J., Ren, X., Brune, W. H., Olson, J. R., Crawford, J. H., Fried, A., Huey, L. G., Cohen, R. C., Heikes, B., Singh, H. B., Blake, D. R., Sachse, G. W., Diskin, G. S., Hall, S. R., and Shetter, R. E.: Airborne measurement of $\mathrm{OH}$ reactivity during INTEX-B, Atmos. Chem. Phys., 9, 163-173, https://doi.org/10.5194/acp-9163-2009, 2009.

Matsunaga, A. and Ziemann, P. J., Gas-Wall Partitioning of Organic Compounds in a Teflon Film Chamber and Potential Effects on Reaction Product and Aerosol Yield Measurements, Aerosol. Sci. Technol., 44, 881-892, 2010.

Müller, L., Reinnig, M.-C., Naumann, K. H., Saathoff, H., Mentel, T. F., Donahue, N. M., and Hoffmann, T.: Formation of 3methyl-1,2,3-butanetricarboxylic acid via gas phase oxidation of pinonic acid - a mass spectrometric study of SOA aging, Atmos. Chem. Phys., 12, 1483-1496, https://doi.org/10.5194/acp12-1483-2012, 2012.

Ortega, A. M., Hayes, P. L., Peng, Z., Palm, B. B., Hu, W., Day, D. A., Li, R., Cubison, M. J., Brune, W. H., Graus, M., Warneke, C., Gilman, J. B., Kuster, W. C., Gouw, J. de, GutiérrezMontes, C., and Jimenez, J. L.: Real-time measurements of secondary organic aerosol formation and aging from ambient air in an oxidation flow reactor in the Los Angeles area, Atmos. Chem. Phys., 16, 7411-7433, https://doi.org/10.5194/acp16-7411-2016, 2016.

Paglione, M., Saarikoski, S., Carbone, S., Hillamo, R., Facchini, M. C., Finessi, E., Giulianelli, L., Carbone, C., Fuzzi, S., Moretti, F., Tagliavini, E., Swietlicki, E., Stenström, K. E., Prévôt, A. S. H., Massoli, P., Canaragatna, M., Worsnop, D., and Decesari, S.: Primary and secondary biomass burning aerosols determined by proton nuclear magnetic resonance $\left({ }^{1} \mathrm{H}-\mathrm{NMR}\right)$ spectroscopy during the 2008 EUCAARI campaign in the Po Valley (Italy), Atmos. Chem. Phys., 14, 5089-5110, https://doi.org/10.5194/acp14-5089-2014, 2014a.

Paglione, M., Kiendler-Scharr, A., Mensah, A. A., Finessi, E., Giulianelli, L., Sandrini, S., Facchini, M. C., Fuzzi, S., Schlag, P., Piazzalunga, A., Tagliavini, E., Henzing, J. S., and Decesari, S.: Identification of humic-like substances (HULIS) in oxygenated organic aerosols using NMR and AMS factor analyses and liquid chromatographic techniques, Atmos. Chem. Phys., 14, 2545, https://doi.org/10.5194/acp-14-25-2014, 2014b.

Palm, B. B., Campuzano-Jost, P., Ortega, A. M., Day, D. A., Kaser, L., Jud, W., Karl, T., Hansel, A., Hunter, J. F., Cross, E. S., Kroll, J. H., Peng, Z., Brune, W. H., and Jimenez, J. L.: In situ secondary organic aerosol formation from ambient pine forest air using an oxidation flow reactor, Atmos. Chem. Phys., 16, 2943 2970, https://doi.org/10.5194/acp-16-2943-2016, 2016.

Peng, Z., Day, D. A., Stark, H., Li, R., Lee-Taylor, J., Palm, B. B., Brune, W. H., and Jimenez, J. L.: $\mathrm{HO}_{x}$ radical chemistry in oxidation flow reactors with low-pressure mercury lamps systematically examined by modeling, Atmos. Meas. Tech., 8, 4863-4890, https://doi.org/10.5194/amt-8-4863-2015, 2015.

Peng, Z., Day, D. A., Ortega, A. M., Palm, B. B., Hu, W., Stark, H., Li, R., Tsigaridis, K., Brune, W. H., and Jimenez, J. L.: Non-OH chemistry in oxidation flow reactors for the study of at- 
mospheric chemistry systematically examined by modeling, Atmos. Chem. Phys., 16, 4283-4305, https://doi.org/10.5194/acp16-4283-2016, 2016.

Putaud, J.-P., Van Dingenen, R., Alastuey, A., Bauer, H., Birmili, W., Cyrys, J., Flentje, H., Fuzzi, S., Gehrig, R., Hansson, H. C., Harrison, R. M., Herrmann, H., Hitzenberger, R., and Hüglin, C.: A European aerosol phenomenology - 3: Physical and chemical characteristics of particulate matter from 60 rural, urban, and kerbside sites across Europe, Atmos. Environ., 44, 1308-1320, 2010.

Pye, H. O. T., Chan, A. W. H., Barkley, M. P., and Seinfeld, J. H.: Global modeling of organic aerosol: the importance of reactive nitrogen $\left(\mathrm{NO}_{x}\right.$ and $\left.\mathrm{NO}_{3}\right)$, Atmos. Chem. Phys., 10, 1126111276, https://doi.org/10.5194/acp-10-11261-2010, 2010.

Reemtsma, T., These, A., Venkatachari, P., Xia, X., Hopke, P. K., Springer, A., and Linscheid, M.: Identification of fulvic acids and sulfated and nitrated analogues in atmospheric aerosol by electrospray ionization Fourier transform ion cyclotron resonance mass spectrometry, Anal. Chem., 78, 8299-8304, 2006.

Renbaum, L. H. and Smith, G. D.: Artifacts in measuring aerosol uptake kinetics: the roles of time, concentration and adsorption, Atmos. Chem. Phys., 11, 6881-6693, https://doi.org/10.5194/acp-11-6881-2011, 2011.

Rissanen, M. P., Kurtén, T., Sipilä, M., Thornton, J. A., Kangasluoma, J., Sarnela, N., Junninen, H., Jørgensen, S., Schallhart, S., Kajos, M. K., Taipale, R., Springer, M., Mentel, T. F., Ruuskanen, T., Petäjä, T., Worsnop, D. R., Kjaergaard, H. G., and Ehn, M. J.: The formation of highly oxidized multifunctional products in the ozonolysis of cyclohexene, Am. Chem. Soc., 136, 1559615606, 2014.

Riva, M., Budisulistiorini, S. H., Chen, Y., Zhang, Z., D’Ambro, E. L., Zhang, X., Gold, A., Turpin, B. J., Thornton, J. A., Canagaratna, M. R., and Surratt, J. D.: Chemical characterization of secondary organic aerosol from oxidation of isoprene hydroxyhydroperoxides, Environ. Sci. Technol., 50, 9889-9899, 2016.

Robinson, A. L., Donahue, N. M., Shrivastava, M. K., Weitkamp, E. A., Sage, A. M., Grieshop, A. P., Lane, T. E., Pierce, J. R., and Pandis, S. N.: Rethinking Organic Aerosols: Semivolatile Emissions and Photochemical Aging, Science, 315, 1259-1262, 2007.

Sandrini, S., Pinxteren D. V., Giulianelli. L., Herrmann, H., Poulain, L., Facchini, M. C., Gilardoni, S., Rinaldi, M., Paglione, M., Turpin, B. J., Pollini, F., Bucci, S., Zanca, N., and Decesari, S.: Size-resolved aerosol composition at an urban and a rural site in the Po Valley in summertime: implications for secondary aerosol formation, Atmos. Chem. Phys., 16, 1087910897,https://doi.org/10.5194/acp-16-10879-2016, 2016.

Slowik, J. G., Wong, J. P. S., and Abbatt, J. P. D.: Realtime, controlled $\mathrm{OH}$-initiated oxidation of biogenic secondary organic aerosol, Atmos. Chem. Phys., 12, 9775-9790, https://doi.org/10.5194/acp-12-9775-2012, 2012.

Szmigielski, R., Surratt, J. D., Gomez-Gonzalez, Y., Van der Veken, P., Kourtchev, I., Vermeylen, R., Blockhuys, F., Jaoui, M., Kleindienst, T. E., Lewandowski, M., Offenberg, J. H., Edney, E. O., Seinfeld, J. H., Maenhaut, W., and Claeys, M.: 3-Methyl-1,2,3Butanetricarboxylic Acid: An Atmospheric Tracer for Terpene Secondary Organic Aerosol, Geophys. Res. Lett., 34, L24811, https://doi.org/10.1029/2007g1031338, 2007.

Tagliavini, T., Moretti, F., Decesari, S., Facchini, M. C., Fuzzi, S., and Maenhaut, W.: Functional group analysis by $\mathrm{H}$
$\mathrm{NMR} /$ chemical derivatization for the characterization of organic aerosol from the SMOCC field campaign, Atmos. Chem. Phys., 6, 1003-1019, https://doi.org/10.5194/acp-6-1003-2006, 2006.

Tkacik, D. S., Lambe, A. T., Jathar, S.,Li, X.,Presto, A. A., Zhao, Y., Blake, D. R., Meinardi, S., Jayne, J. T., Croteau, P. L., and Robinson, A. L.: Secondary organic aerosol formation from inuse motor vehicle emissions using a Potential Aerosol Mass reactor, Environ. Sci. Technol., 48, 11235-11242, 2014.

Tsigaridis, K., Daskalakis, N., Kanakidou, M., Adams, P. J., Artaxo, P., Bahadur, R., Balkanski, Y., Bauer, S. E., Bellouin, N., Benedetti, A., Bergman, T., Berntsen, T. K., Beukes, J. P., Bian, H., Carslaw, K. S., Chin, M., Curci, G., Diehl, T., Easter, R. C., Ghan, S. J., Gong, S. L., Hodzic, A., Hoyle, C. R., Iversen, T., Jathar, S., Jimenez, J. L., Kaiser, J. W., Kirkevåg, A., Koch, D., Kokkola, H., Lee, Y. H., Lin, G., Liu, X., Luo, G., Ma, X., Mann, G. W., Mihalopoulos, N., Morcrette, J.-J., Müller, J.-F., Myhre, G., Myriokefalitakis, S., Ng, N. L., O’Donnell, D., Penner, J. E., Pozzoli, L., Pringle, K. J., Russell, L. M., Schulz, M., Sciare, J., Seland, Ø., Shindell, D. T., Sillman, S., Skeie, R. B., Spracklen, D., Stavrakou, T., Steenrod, S. D., Takemura, T., Tiitta, P., Tilmes, S., Tost, H., van Noije, T., van Zyl, P. G., von Salzen, K., Yu, F., Wang, Z., Wang, Z., Zaveri, R. A., Zhang, H., Zhang, K., Zhang, Q., and Zhang, X.: The AeroCom evaluation and intercomparison of organic aerosol in global models, Atmos. Chem. Phys., 14, 10845-10895, https://doi.org/10.5194/acp-1410845-2014, 2014.

White, S. J., Jamie, I. M., and Angove, D. E.: Chemical characterisation of semi-volatile and aerosol compounds from the photooxidation of toluene and $\mathrm{NO}_{x}$, Atmos. Environ., 83, 237-244, 2014.

Xu, L., Guo, H., Weber, R. J., and Ng, N. L.: Chemical characterization of water-soluble organic aerosol in contrasting rural and urban environments in the southeastern United States, Environ. Sci. Technol., 51, 78-88, 2017.

Yasmeen, F., Vermeylen, R., Szmigielski, R., Iinuma, Y., Böge, O., Herrmann, H., Maenhaut, W., and Claeys, M.: Terpenylic acid and related compounds: precursors for dimers in secondary organic aerosol from the ozonolysis of $\alpha$ - and $\beta$-pinene, Atmos. Chem. Phys., 10, 9383-9392, https://doi.org/10.5194/acp10-9383-2010, 2010.

Ye, P., Ding, X., Hakala, J., Hofbauer, V., Robinson, E. S., and Donahue, N. M.: Vapor wall loss of semi-volatile organic compounds in a Teflon chamber, Aerosol. Sci. Technol., 50, 822-834, 2016.

Yu, G., Bayer, A. R., Galloway, M. M., Korshavn, K. J., Fry, C. G., and Keutsch, F. N.: Glyoxal in Aqueous Ammonium Sulfate Solutions: Products, Kinetics and Hydration Effects, Environ. Sci. Technol., 45, 6336-6342, 2011.

Zhang, Q., Jimenez, J. L., Canagaratna, M. R., Allan, J. D., Coe, H., Ulbrich, I., Alfarra, M. R., Takami, A., Middlebrook, A. M., Sun, Y. L., Dzepina, K., Dunlea, E., Docherty, K., DeCarlo, P. F., Salcedo, D., Onasch, T., Jayne, J. T., Miyoshi, T., Shimono, A., Hatakeyama, S., Takegawa, N., Kondo, Y., Schneider, J., Drewnick, F., Borrmann, S., Weimer, S., Demerjian, K., Williams, P., Bower, K., Bahreini, R., Cottrell, L., Griffin, R. J., Rautiainen, J., Sun, J. Y., Zhang, Y. M., and Worsnop, D. R.: Ubiquity and dominance of oxygenated species in organic aerosols in anthropogenically-influenced Northern Hemisphere midlatitudes, Geophys. Res. Lett., 34, L13801, https://doi.org/10.1029/2007GL029979, 2007. 
Zhang, X., Cappa, C. D., Jathar, S. H., McVay, R. C., Ensberg, J. J., Kleeman, M. J., and Seinfeld, J. H.: Influence of vapor wall loss in laboratory chambers on yields of secondary organic aerosol, P. N. A. S., 111, 5802-5807, https://doi.org/10.1073/pnas.1404727111, 2014. 